\title{
ALTERNATIVE AND ENHANCED CHEMICAL CLEANING: CORROSION STUDIES RESULTS FY2010
}

September 2010 


\section{DISCLAIMER}

This work was prepared under an agreement with and funded by the U.S. Government. Neither the U. S. Government or its employees, nor any of its contractors, subcontractors or their employees, makes any express or implied:

1. warranty or assumes any legal liability for the accuracy, completeness, or for the use or results of such use of any information, product, or process disclosed; or

2. representation that such use or results of such use would not infringe privately owned rights; or

3. endorsement or recommendation of any specifically identified commercial product, process, or service.

Any views and opinions of authors expressed in this work do not necessarily state or reflect those of the United States Government, or its contractors, or subcontractors.

This document was prepared in conjunction with work accomplished under Contract No. DE-AC09-08SR22470 with the U.S. Department of Energy.

Printed in the United States of America

Prepared For

U.S. Department of Energy 
Key Words:

Sludge Heel

Oxalic Acid Cleaning

Carbon Steel Corrosion

Retention: Permanent

Key References:

Technical Task Plan: SRNL-RP-2010-00645

\section{ALTERNATIVE AND ENHANCED CHEMICAL CLEANING: CORROSION STUDIES RESULTS FY2010}

B. J. Wiersma, SRNL/MST

Issue Date: September 2010

Savannah River National Laboratory Savannah River Nuclear Solutions Aiken, SC 29808

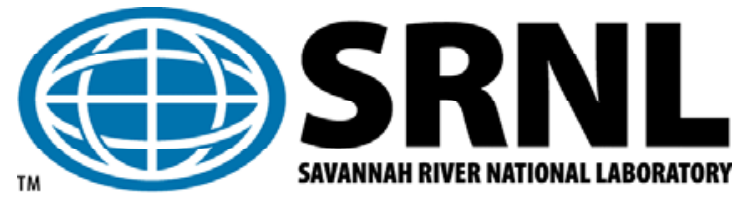




\section{REVIEWS AND APPROVALS}

B. J. Wiersma, Author, SRNL/MST/MA\&CT

Date

A. K. Roy, Technical Reviewer, SRNL/MST/MA\&CT

Date

W. D. King, Program Lead, SRNL/E\&CPT

Date

F. M. Pennebaker, Manager SRNL/E\&CPT

Date

K. E. Zeigler, Manager, SRNL/MST/MA\&CT

Date

S. L. Marra, Manager, SRNL/E\&CPT Research Programs

Date 


\section{TABLE OF CONTENTS}

$\begin{array}{lc}\text { LIST OF TABLES } & 3\end{array}$

$\begin{array}{ll}\text { LIST OF FIGURES } & 4\end{array}$

$\begin{array}{ll}\text { LIST OF FIGURES } & 4\end{array}$

LIST OF ACRONYMS $\quad 5$

$\begin{array}{ll}\text { 1.0 SUMMARY } & 6\end{array}$

$\begin{array}{ll}2.0 \text { BACKGROUND AND INTRODUCTION } & 7\end{array}$

3.0 EXPERIMENTAL METHODS, MATERIALS, AND EQUIPMENT 9

3.1 REAGENTS AND MATERIALS

3.2 ELECTROCHEMICAL CORROSION STUDIES

3.2.1 Corrosion Test Set-up 13

3.2.2 Corrosion Test Methods 13

4.0 EXPERIMENTAL RESULTS 20

4.1 OPEN Circuit Potential (OCP) Results 20

4.2 LinEAR Polarization ReSistanCE RESUlts 26

4.3 CATHOdic Polarization Test Results 34

4.4 CYCLIC POTENTIODYNAMIC POLARIZATION RESUlTS 38

$\begin{array}{ll}5.0 & \mathbf{4 5}\end{array}$

$\begin{array}{ll}\text { 6.0 CONCLUSIONS } & 45\end{array}$

7.0 REFERENCES $\quad 46$

$\begin{array}{ll}\text { 8.0 ACKNOWLEDGEMENTS } & 47\end{array}$ 


\section{LIST OF TABLES}

Table 3-1. Elemental Analysis and Particle Size Data for Metal Phases Tested

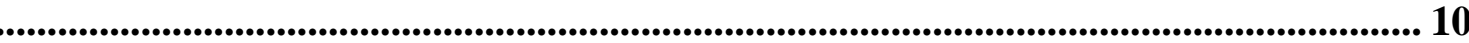

TABLE 3-2. TEST MATRIX FOR ELECTROCHEMICAL STUDIES IN NITRIC/OXALIC ACID...... 11

TABLE 3-3. TEST MATRIX FOR ELECTROCHEMICAL STUDIES IN SULFURIC/OXALIC ACID 12

Table 3-4. Chemical Composition (WT \%) OF A285 Grade C, Carbon SteEl .......... 13

Table 3-5. Mechanical Properties of A285 Grade C, Carbon STEel......................... 13

Table 4-1. Open Circuit Potential Results for Sulfuric/Oxalic Acid Solutions

21

TABle 4-2. Open Circuit Potential Results for Nitric/OXalic ACID SOlutions 22

Table 4-3. General Corrosion Rates for Sulfuric AcID/OXalic ACID REAGENT

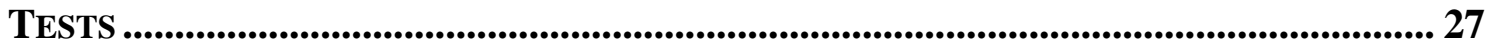

Table 4-4. General Corrosion Rates for Nitric ACID/OXalic ACID REAGENT TESTS 28

Table 4-5. Cathodic Polarization Parameters for Sulfuric ACID ........................ 36

TABle 4-6. Cathodic Polarization Parameters for Nitric ACID ................................. 37

TABLE 4-7. SumMARY OF CPP ReSUltS FOR TeSTs EXHIBITING PITTING ........................... 40 


\section{LIST OF FIGURES}

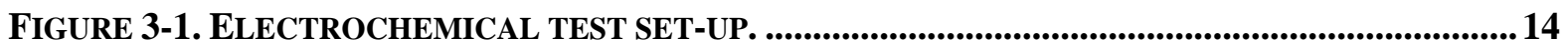

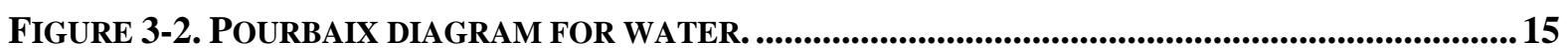

FIGURE 3-3. EXAMPLE OF LINEAR POLARIZATION RESISTANCE CURVE MEASURED DURING

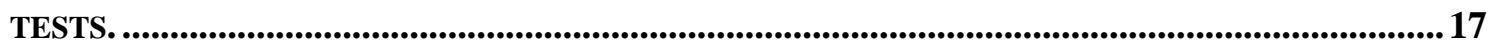

FIGURE 3-4. EXAMPLES OF CATHODIC POLARIZATION CURVES...................................................... 18

FIGURE 3-5. PLOT OF SCHEMATIC CPP DATA SHOWING CHARACTERISTIC POTENTIALS AND CURRENTS.

FIGURE 4-1. OCP RESULTS FOR 0.1 M NITRIC AND 0.05 M SULFURIC ACID REAGENTS AT $45^{\circ} \mathrm{C} .23$

FIGURE 4-2. OCP RESULTS FOR 0.1 M NITRIC ACID WITH PURE OXIDE PHASES AT $75^{\circ} \mathrm{C}$.............23

FIGURE 4-3. OCP RESULTS FOR 0.05 M SULFURIC ACID WITH PURE OXIDE PHASES AT $75^{\circ} \mathrm{C} . . . . .24$

FIGURE 4-4. OCP RESULTS FOR 0.5 M NITRIC ACID WITH SLUDGE SIMULANTS AT $75^{\circ} \mathrm{C} . \ldots . . . . . . . .25$

FIGURE 4-5. OCP RESULTS FOR 0.25 M SULFURIC ACID WITH SLUDGE SIMULANTS AT $75^{\circ} \mathrm{C} . . . .25$

FIGURE 4-6. CORROSION RATES FOR 0.5 M NITRIC ACID WITH VARIOUS SOLID PHASES AT $75^{\circ} \mathrm{C}$.

FIGURE 4-7. CORROSION RATES FOR 0.1 M NITRIC ACID WITH VARIOUS SOLID PHASES AT $75^{\circ} \mathrm{C}$.

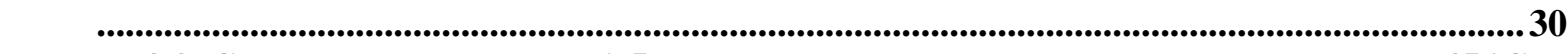

FIGURE 4-8. CORROSION RATES FOR 0.5 M NITRIC ACID WITH VARIOUS SOLID PHASES AT $45^{\circ} \mathrm{C}$.

FIGURE 4-9. CORROSION RATES FOR 0.1 M NITRIC ACID WITH SLUDGE SIMULANTS AT $45^{\circ} \mathrm{C} . . . .31$

FIGURE 4-10. CORROSION RATES FOR 0.25 M SULFURIC ACID WITH VARIOUS SOLID PHASES AT 75

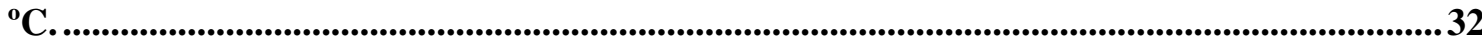

FIGURE 4-11. CORROSION RATES FOR 0.05 M SULFURIC ACID WITH VARIOUS SOLID PHASES AT 75

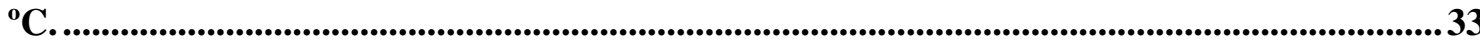

FIGURE 4-12. CORROSION RATES FOR 0.25 M SULFURIC ACID WITH VARIOUS SOLID PHASES AT 45

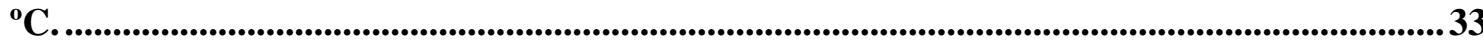

FIGURE 4-13. CORROSION RATES FOR 0.05 M SULFURIC ACID WITH SLUDGE SIMULANTS AT $45^{\circ} \mathrm{C}$.

FIGURE 4-14. CATHODIC POLARIZATION CURVES IN: (A) 0.5 M NITRIC AND 1 WT.\% OXALIC ACIDS AT $45^{\circ} \mathrm{C}$, AND (B) MAGNETITE PURE PHASE OXIDE, 0.25 M SULFURIC ACID AND 1

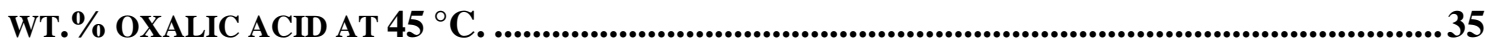

FIGURE 4-15.CPP DIAGRAM FOR CARBON STEEL WITH MAGNETITE IN 0.1 M NITRIC AND 1 WT. \%

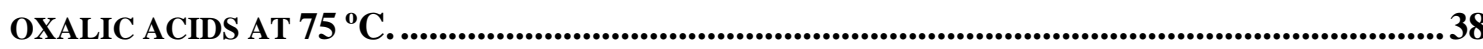

FIGURE 4-16. ELECTRODE MICROGRAPH AFTER EXPOSURE TO MAGNETITE IN 0.1 M NITRIC AND

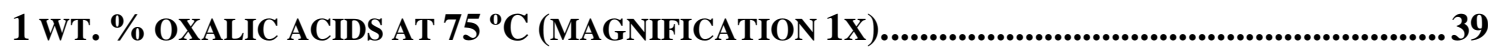

FIGURE 4-17. CPP DIAGRAM IN 0.05 M SULFURIC WITH MAGNETITE AT 75 C................................ 41

FIGURE 4-18. ELECTRODE MICROGRAPH SHOWING PITTING AFTER EXPOSURE TO 0.05 M SULFURIC WITH MAGNETITE AT $75^{\circ} \mathrm{C}$ (MAGNIFICATION: 1X FOR (A), 50X FOR (B)), ............. 41

FIGURE 4-19. CPP DIAGRAM IN 0.05 M SULFURIC WITH PUREX SIMULANT AT $75^{\circ} \mathrm{C}$................... 42

FIGURE 4-20. ELECTRODE MICROGRAPH SHOWING PITTING AFTER EXPOSURE TO 0.05 M SULFURIC ACID WITH PUREX AT $75^{\circ} \mathrm{C}$ (MAGNIFICATION: 1X FOR (A), 90X FOR (B))........... 42

FIGURE 4-21. CPP DIAGRAM IN 0.05 M SULFURIC ACID WITH PUREX SIMULANT AT $45^{\circ} \mathrm{C}$........ 43

FIGURE 4-22. ELECTRODE MICROGRAPH SHOWING MINOR PITTING AFTER EXPOSURE TO $0.05 \mathrm{M}$ SULFURIC ACID WITH PUREX SIMULANT AT $45^{\circ} \mathrm{C}$ (MAGNIFICATION: 1X FOR (A), 90X FOR

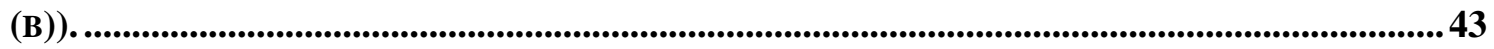

FIGURE 4-23. CPP DIAGRAM IN 0.1M NITRIC ACID WITH PUREX SIMULANT AT $45^{\circ} \mathrm{C}$................44

FIGURE 4-24. ELECTRODE MICROGRAPHS SHOWING MINOR PITTING AFTER EXPOSURE TO 0.1 M NITRIC ACID WITH PUREX SIMULANT AT $45^{\circ} \mathrm{C}$ (MAGNIFICATION: 1X FOR (A), 90X FOR (B)). 


\section{LIST OF ACRONYMS}

$\begin{array}{ll}\text { AECC } & \text { Alternative Enhanced Chemical Cleaning } \\ \text { ASTM } & \\ \text { CP } & \text { Cathodic Polarization } \\ \text { CPP } & \text { Cyclic Potentiodynamic Polarization } \\ \text { DOE } & \text { Department of Energy } \\ \text { ESP } & \text { Environmental Simulation Program } \\ \text { HM } & \\ \text { ICP-ES } & \text { Inductively Coupled Plasma-Emission Spectroscopy } \\ \text { LPR } & \text { Linear Polarization Resistance } \\ \text { NHE } & \text { Normal Hydrogen Electrode } \\ \text { OCP } & \text { Open Circuit Potential } \\ \text { PUREX } & \text { Plutonium Uranium Reduction Extraction } \\ \text { SRNL } & \text { Savannah River National Laboratory } \\ \text { SRS } & \text { Savannah River Site } \\ \text { XRD } & \text { X-ray Diffraction }\end{array}$




\subsection{SUMMARY}

Due to the need to close High Level Waste storage tanks, chemical cleaning methods are needed for the removal of sludge heel materials remaining at the completion of mechanical tank cleaning efforts. Oxalic acid is considered the preferred cleaning reagent for heel dissolution of iron-based sludge. However, the large quantity of chemical reagents added to the tank farm from oxalic acid based cleaning has significant downstream impacts. Optimization of the oxalic acid cleaning process can potentially reduce the downstream impacts from chemical cleaning. To optimize oxalic acid usage, a detailed understanding of the chemistry of oxalic acid based sludge dissolution is required. Additionally, other acidic systems may be required for specific waste components that have low solubility in oxalic acid, and as a means to reduce oxalic acid usage in general.

Electrochemical corrosion studies were conducted with 1 wt. \% oxalic acid at mineral acid concentrations above and below the optimal conditions for this oxalic acid concentration. Testing environments included pure reagents, pure iron and aluminum phases, and sludge simulants. Mineral acid concentrations greater than $0.2 \mathrm{M}$ and temperatures greater than 50 ${ }^{\circ} \mathrm{C}$ result in unacceptably high corrosion rates. Results showed that manageable corrosion rates of carbon steel can be achieved at dilute mineral acid concentrations (i.e. less than 0.2 M) and low temperatures based on the contact times involved. Therefore, it is recommended that future dissolution and corrosion testing be performed with a dilute mineral acid and a less concentrated oxalic acid (e.g., 0.5 wt.\%) that still promotes optimal dissolution. This recommendation requires the processing of greater water volumes than those for the baseline process during heel dissolution, but allows for minimization of oxalic acid additions.

The following conclusions can be drawn from the test results.

- In both nitric and sulfuric acid based reagents, the low temperature and dilute concentration environment resulted in carbon steel corrosion rates that were less than 150 mpy. These rates are manageable in that chemical cleaning processes could proceed for limited time without significant wall loss. Further optimization of the Alternative Enhance Chemical Cleaning (AECC) process should focus on testing in solutions of this dilute concentration and low temperature regime.

- In general, for the nitric acid based reagent, the aluminum oxide phase environments resulted in higher corrosion rates than the iron oxide phase environments.

- In general, for the sulfuric acid based reagent, the iron oxide phase environments resulted in higher corrosion rates than the aluminum oxide phase environments.

- In general, for the nitric acid based reagent, the HM sludge simulant environments resulted in higher corrosion rates than the PUREX sludge simulant environments. This result agrees with the previous observation that the aluminum oxide phases are more aggressive than the iron oxide phase environments in the nitric acid reagent.

- Pitting was more likely to occur in the sulfuric acid based reagents than in the nitric acid based reagents.

- Pitting occurred only in the iron based pure oxide phases and the sludge simulants. No pitting was observed in the aluminum based pure oxide phases. 
- $\quad$ Pitting tended to occur more frequently in tests that involved the dilute mineral acid reagent.

- Pitting was more severe at the higher temperature for a given mineral acid concentration.

- Pitting was more severe at a higher mineral acid concentration for a given temperature.

- Based on the combined results of the open circuit potential and cathodic polarization testing, there was a low propensity for hydrogen evolution in solutions where sludge has been dissolved.

\subsection{BACKGROUND AND INTRODUCTION}

As efforts continue to treat and dispose of millions of gallons of legacy radioactive materials from the production of nuclear weapons, non-compliant waste storage tanks will gradually be emptied of the bulk waste volume leaving heel materials requiring removal prior to tank closure. The waste heel slurries are distributed on the floor of large tanks, which frequently contain numerous obstructions that limit the effectiveness of mechanical removal methods. As a result, chemical cleaning methods are needed for the effective removal of the heels as well as chemical scales that are present on the tank walls and other interior surfaces. Oxalic acid is the preferred cleaning reagent for heel dissolution, particularly for iron-based sludge. While several recent literature reviews [1-3] and a Systems Engineering Evaluation [4] have considered many known methods of sludge dissolution, oxalic acid remains the chemical dissolution reagent of choice. Oxalic acid is an industry standard used for the cleaning and maintenance of nuclear power plants, although these operations often involve the removal of relatively small volumes of chemical scale materials with dilute acid followed by regeneration of the acid for reuse [5].

Numerous waste tanks at two DOE sites, namely Hanford, WA and Aiken, SC (Savannah River Site - SRS), contain sludge and salt heel solids (approaching 5,000 gallons per tank at SRS) at the conclusion of bulk waste removal and heel washing campaigns. The current baseline chemical cleaning process for heel removal at SRS involves the addition of $8 \mathrm{wt} . \%$ oxalic acid to the waste tanks in several treatment cycles. More concentrated oxalic acid is preferred in this case because available tank farm volume is limited and evaporation to remove excess liquid is expensive. The large mass of waste requiring treatment makes the utilization of traditional techniques such as ion exchange for acid regeneration impractical. As a result, sludge dissolution with oxalic acid involves the addition of large amounts of oxalate to the tank farm inventory. The addition of oxalic acid and the subsequent addition of sodium hydroxide (required after heel removal to make the waste stream compatible with interim storage vessels) have significant impacts on downstream processes.

The baseline chemical cleaning method has recently been used for heel removal in two SRS waste tanks with limited success [6,7]. Lower than expected amounts of solids were removed from the tanks in each case. The baseline method has not been optimized to minimize the use of oxalic acid, and the results indicate that better understanding of sludge dissolution chemistry in oxalic acid is needed in order to achieve more consistent and effective results. Given that numerous waste tanks are targeted for closure within the next 
decade, there is an urgent need to understand and optimize the chemical cleaning process for heel removal. SRS operations is currently developing a chemical cleaning process for heel removal involving an oxalate destruction technology. In a separate effort, as part of the EM31 Alternative Enhanced Chemical Cleaning (AECC) program, the Savannah River National Laboratory (SRNL) is working to refine the baseline chemical cleaning process to optimize sludge dissolution. This effort includes evaluations of various acid additions (including oxalic) and combinations of acids for sludge dissolution and the impact of these additions on tank corrosion. The latest results from this testing are presented in this report.

Nitric and sulfuric acids were evaluated in this testing as supplemental proton sources to promote the dissolution of the iron and aluminum oxide phases. In contrast to previous testing where mineral acids were added to adjust the $\mathrm{pH}$, this testing involved the use of oxalic/mineral acid mixtures. This approach was considered more suitable to large scale waste processing operations. Minimal downstream impacts are expected from the addition of nitrate, since SRS waste streams already contain significant sodium nitrate salts. Sulfate could potentially have negative downstream impact associated with the formation of separate phases during waste vitrification.

The waste tanks at SRS and Hanford are constructed of carbon steel. Carbon steel corrodes rapidly in most acidic environments. For example, its corrosion rates in nitric acid at $25{ }^{\circ} \mathrm{C}$ at $1 \mathrm{M}$ and $6 \mathrm{M}$ concentrations are 2 inches/yr and 13 inches/yr, respectively [8]. The corrosion rate for carbon steel in $0.75 \mathrm{M}$ sulfuric acid at $45{ }^{\circ} \mathrm{C}$ is approximately 0.8 inches per year [9]. One of the reasons for selecting oxalic acid for chemical cleaning is that carbon steel corrodes at a relatively lower rate of approximately 0.06 inches per year [10]. For a short contact time between the oxalic acid and the steel tank, on the order of two months, this results in a loss of approximately 0.01 inch from the tank wall. This amount of corrosion does not significantly impact the structural integrity of the tank [11] or the performance assessment analysis [12]. Ideally, the wall thickness loss that results from the alternative chemical cleaning process would be at a similar "manageable" degree.

Previous testing in oxalic acid/nitric acid mixtures suggested that the corrosion rate for carbon steel in dilute acid mixtures (i.e., $0.3 \mathrm{M}$ nitric acid) would result in a "manageable" amount of degradation over a short period of time [13]. Thus, the concentrations of nitric acid or sulfuric acid utilized for the testing ranged between 0.05 and $0.5 \mathrm{M}$. The expected oxalic acid concentration for the process will be on the order of $1 \mathrm{wt} \%$. The objective of the corrosion testing was to obtain data (i.e., general corrosion rates and localized corrosion susceptibility) for carbon steel exposed to an oxalic acid/mineral acid mixture.

Additionally, tests have been performed in acidic solutions that contained metal oxide solids [14]. These environmental conditions simulated the actual chemical cleaning process. Previous testing has shown that the corrosion rate in oxalic acid with solids is typically lower than the corrosion in the acid without solids. Several simulants containing solids were utilized to determine if the oxalic/mineral acid reagent would exhibit similar behavior: 1) hematite, 2) magnetite, 3) boehmite, 4) gibbsite, 5) solids from a HM waste simulant [15], and 6) solids from a PUREX simulant [15]. 
The anticipated temperature range in the treatment tank will be the same as that proposed for the enhanced chemical cleaning process, between 45 and $75^{\circ} \mathrm{C}$ [14]. In order to obtain better dissolution of the solids, the waste is typically agitated by pumps. Previous laboratory testing has suggested that agitation resulted in higher general corrosion rates [10]. Therefore, the simulants were agitated during this testing.

\subsection{EXPERIMENTAL METHODS, MATERIALS, AND EQUIPMENT}

\subsection{REAGENTS AND MATERIALS}

Mixtures of oxalic acid and a mineral acid were utilized as reagents for the corrosion studies. Nitric acid and sulfuric acid were the two mineral acids that were evaluated. The concentration of the oxalic acid in each test solution was $1 \mathrm{wt} \%$, while the mineral acids were examined both at high and low concentrations. For nitric acid the concentrations were 0.1 and $0.5 \mathrm{M}$, while for sulfuric acid the concentrations were $0.05 \mathrm{M}$ and $0.25 \mathrm{M}$. Reagent solutions were prepared by adding oxalic acid $\left(\mathrm{H}_{2} \mathrm{C}_{2} \mathrm{O}_{4} \cdot 2 \mathrm{H}_{2} \mathrm{O}\right)$ crystals (i.e., 1 wt.\% is $14 \mathrm{~g}$ per liter of solution) to either the nitric or sulfuric acid solutions. The mineral acid solutions were prepared from either concentrated nitric $(\sim 16 \mathrm{M})$ or concentrated sulfuric $(\sim 18 \mathrm{M})$ acids.

Corrosion testing in a mixture of metal oxide and reagent was also performed. Pure metal oxide phases were purchased from Aldrich, Strem Chemicals, Inc. (Newburyport, MA), and Almatis, Inc. (Bauxite, AK). Elemental analysis results for all of the metal phases are provided in Table 3-1. For the iron phases, all metals other than iron were present at concentrations lower than $1 \mathrm{wt} . \%$. The measured iron content was lower than the theorical value for every sample. For the gibbsite sample, all metals other than aluminum were present at concentrations lower than $1 \mathrm{wt} . \%$. In this case, the measured aluminum content was higher than the theoretical value. Correction for water content does not explain the magnitude of the differences between measured and theoretical values, since the water content of all samples was $\leq 2.5$ wt. \%. Presumably, analysis error such as incomplete acid digestion caused this discrepancy. As-received and sonicated particle size analysis results (Microtrac) are also provided in Table 3-1. Sample sonication was conducted due to the observation of large particle agglomerates in some samples. Sonication resulted in the reduction of the mean particle diameter to $\leq 10 \mu \mathrm{m}$. The size distributions after sonication may be more representative of the solid phase after agitation during batch contact testing. $\mathrm{XRD}$ results also indicated a high degree of purity for all crystalline phases [16]. 
SRNL-STI-2010-00555, REV. 0

Table 3-1. Elemental Analysis and Particle Size Data for Metal Phases Tested

\begin{tabular}{|c|c|c|c|c|c|c|}
\hline Phase & $\begin{array}{l}\text { Source and } \\
\text { Catalogue \# }\end{array}$ & $\begin{array}{c}\text { Al } \\
\text { Wt. \% }\end{array}$ & $\begin{array}{c}\text { Fe } \\
\text { Wt. \% }\end{array}$ & $\begin{array}{c}\text { Theoretical } \\
{\text { Wt. }{ }^{\mathrm{a}}}\end{array}$ & $\begin{array}{c}\text { As-received } \\
\text { Mean } \\
\text { Particle } \\
\text { Diameter } \\
\text { (um) } \\
\end{array}$ & $\begin{array}{c}\text { Sonicated } \\
\text { Mean } \\
\text { Particle } \\
\text { Diameter } \\
\text { (um) } \\
\end{array}$ \\
\hline $\begin{array}{l}\text { Hematite } \\
\left(\mathrm{Fe}_{2} \mathrm{O}_{3}\right)\end{array}$ & $\begin{array}{c}\text { Strem } \\
93-2617 \\
\end{array}$ & --- & 65.40 & 69.9 & 2.94 & 0.99 \\
\hline $\begin{array}{l}\text { Magnetite } \\
\left(\mathrm{Fe}_{3} \mathrm{O}_{4}\right)\end{array}$ & $\begin{array}{c}\text { Strem } \\
93-2616 \\
\end{array}$ & --- & 62.20 & 72.4 & 5.71 & 0.90 \\
\hline Boehmite & NA & 55.60 & 0.07 & $45.0(\mathrm{Al})$ & 723.8 & 0.48 \\
\hline $\begin{array}{l}\text { Gibbsite } \\
\left(\mathrm{Al}(\mathrm{OH})_{3}\right)\end{array}$ & Almatis & 42.60 & 0.04 & 34.6 (Al) & 13.54 & 10.38 \\
\hline
\end{tabular}

${ }^{a}$ theoretical values for iron based on the formula weight unless otherwise indicated

${ }^{b}$ particle size analysis following 6 minute sonication

To prepare the mixture for the corrosion tests, $5 \mathrm{~g}$ of a solid oxide (e.g., magnetite) was added to $250 \mathrm{ml}$ of reagent (liquid:solid mass ratio: $\sim 50: 1$ ). The mixtures were placed in a shaker oven at a temperature of $50{ }^{\circ} \mathrm{C}$ for two weeks to allow for dissolution and equilibration. Upon removal from the oven, the mixtures were transported in a closed container to the corrosion testing laboratory to prevent any photochemical reactions.

Two sludge simulants were also added to the reagents for evaluation. The sludge simulants were HM, a sludge that contains both aluminum and iron oxides that is found predominantly in the H-tank farm facility, and PUREX, a sludge that contains iron oxides that is found in both F- and $\mathrm{H}$ tank farm facilities. These sludge simulants contain other metals and ions in addition to the pure phase oxides [15]. To prepare the mixture for the corrosion tests, $5 \mathrm{~g}$ of wet sludge simulant solids (e.g., HM or PUREX) was added to $250 \mathrm{ml}$ of reagent. The mixtures were placed in a shaker oven at a temperature of $50{ }^{\circ} \mathrm{C}$ for two weeks to allow for dissolution and equilibration. Upon removal from the oven, the mixtures were transported in a closed container to the laboratory for corrosion testing.

The compositions of the test mixtures used for the nitric and sulfuric acid reagents are shown in Tables 3-2 and 3-3, respectively. The test temperatures were 45 and $75{ }^{\circ} \mathrm{C}$, the same as those utilized for the enhanced chemical cleaning corrosion studies [14]. The mixtures were agitated during corrosion testing, and were performed in closed containers to limit photochemical reactions. Tests with pure reagents are believed to be representative of corrosion conditions during initial contact of the solutions with the carbon steel waste tanks. Tests with pre-equilibrated and partially dissolved solid phases are generally more representative of corrosion conditions after the first few days of contact between the solutions and the tanks. 
SRNL-STI-2010-00555, REV. 0

Table 3-2. Test Matrix for Electrochemical Studies in Nitric/Oxalic Acid.

\begin{tabular}{|c|c|c|c|c|c|c|c|c|c|}
\hline Test \# & Nitric (M) & Oxalic (wt.\%) & Magnetite & Hematite & Boehmite & Gibbsite & HM Simulant & PUREX Simulant & Temperature $\left({ }^{\circ} \mathrm{C}\right)$ \\
\hline 1 & 0.1 & 1 & $\mathrm{~N}$ & $\mathrm{~N}$ & $\mathrm{~N}$ & $\mathrm{~N}$ & $\mathrm{~N}$ & $\mathrm{~N}$ & 45 \\
\hline 2 & 0.5 & 1 & $\bar{N}$ & $\mathrm{~N}$ & $\mathrm{~N}$ & $\mathrm{~N}$ & $\mathrm{~N}$ & $\mathrm{~N}$ & 45 \\
\hline 3 & 0.1 & 1 & $\mathrm{~N}$ & $\mathrm{~N}$ & $\mathrm{~N}$ & $\mathrm{~N}$ & $\mathrm{~N}$ & $\mathrm{~N}$ & 75 \\
\hline 4 & 0.5 & 1 & $\mathrm{~N}$ & $\mathrm{~N}$ & $\mathrm{~N}$ & $\mathrm{~N}$ & $\mathrm{~N}$ & $\mathrm{~N}$ & 75 \\
\hline 5 & 0.1 & 1 & $\bar{Y}$ & $\mathrm{~N}$ & $\mathrm{~N}$ & $\mathrm{~N}$ & $\mathrm{~N}$ & $\mathrm{~N}$ & 75 \\
\hline 6 & 0.1 & 1 & $\mathrm{~N}$ & $\mathrm{Y}$ & $\mathrm{N}$ & $\mathrm{N}$ & $\mathrm{N}$ & $\mathrm{N}$ & 75 \\
\hline 7 & 0.1 & 1 & $\bar{N}$ & $\mathrm{~N}$ & $\bar{Y}$ & $\mathrm{~N}$ & $\overline{\mathrm{N}}$ & $\mathrm{N}$ & 75 \\
\hline 8 & 0.1 & 1 & $\mathrm{~N}$ & $\mathrm{~N}$ & $\mathrm{~N}$ & $\bar{Y}$ & $\mathrm{~N}$ & $\mathrm{~N}$ & 75 \\
\hline 9 & 0.1 & 1 & $\mathrm{~N}$ & $\mathrm{~N}$ & $\mathrm{~N}$ & $\mathrm{~N}$ & $\mathrm{Y}$ & $\mathrm{N}$ & 75 \\
\hline 10 & 0.1 & 1 & $\mathrm{~N}$ & $\mathrm{~N}$ & $\mathrm{~N}$ & $\mathrm{~N}$ & $\mathrm{~N}$ & $\mathrm{Y}$ & 75 \\
\hline 11 & 0.5 & 1 & $\mathrm{Y}$ & $\mathrm{N}$ & $\mathrm{N}$ & $\mathrm{N}$ & $\mathrm{N}$ & $\mathrm{N}$ & 45 \\
\hline 12 & 0.5 & 1 & $\mathrm{Y}$ & $\mathrm{N}$ & $\mathrm{N}$ & $\mathrm{N}$ & $\mathrm{N}$ & $\mathrm{N}$ & 75 \\
\hline 13 & 0.5 & 1 & $\mathrm{~N}$ & $\mathrm{Y}$ & $\bar{N}$ & $\mathrm{~N}$ & $\bar{N}$ & $\mathrm{~N}$ & 45 \\
\hline 14 & 0.5 & 1 & $\mathrm{~N}$ & $\mathrm{Y}$ & $\mathrm{N}$ & $\mathrm{N}$ & $\mathrm{N}$ & $\mathrm{N}$ & 75 \\
\hline 15 & 0.5 & 1 & $\mathrm{~N}$ & $\mathrm{~N}$ & $Y$ & $\mathrm{~N}$ & $\mathrm{~N}$ & $\mathrm{~N}$ & 45 \\
\hline 16 & 0.5 & 1 & $\mathrm{~N}$ & $\mathrm{~N}$ & $\mathrm{Y}$ & $\mathrm{N}$ & $\mathrm{N}$ & $\mathrm{N}$ & 75 \\
\hline 17 & 0.5 & 1 & $\mathrm{~N}$ & $\mathrm{~N}$ & $\mathrm{~N}$ & $\mathrm{Y}$ & $\mathrm{N}$ & $\mathrm{N}$ & 45 \\
\hline 18 & 0.5 & 1 & $\mathrm{~N}$ & $\mathrm{~N}$ & $\mathrm{~N}$ & $\mathrm{Y}$ & $\mathrm{N}$ & $\mathrm{N}$ & 75 \\
\hline 19 & 0.1 & 1 & $\mathrm{~N}$ & $\mathrm{~N}$ & $\mathrm{~N}$ & $\mathrm{~N}$ & $\bar{Y}$ & $\mathrm{~N}$ & 45 \\
\hline 20 & 0.5 & 1 & $\mathrm{~N}$ & $\mathrm{~N}$ & $\mathrm{~N}$ & $\mathrm{~N}$ & $\bar{Y}$ & $\mathrm{~N}$ & 75 \\
\hline 21 & 0.1 & 1 & $\mathrm{~N}$ & $\mathrm{~N}$ & $\mathrm{~N}$ & $\mathrm{~N}$ & $\mathrm{~N}$ & $\bar{Y}$ & 45 \\
\hline 22 & 0.5 & 1 & $\mathrm{~N}$ & $\mathrm{~N}$ & $\mathrm{~N}$ & $\mathrm{~N}$ & $\mathrm{~N}$ & $\mathrm{Y}$ & 75 \\
\hline
\end{tabular}

$\mathrm{N}$ : None

Y: Present 
SRNL-STI-2010-00555, REV. 0

Table 3-3. Test Matrix for Electrochemical Studies in Sulfuric/Oxalic Acid.

\begin{tabular}{|c|c|c|c|c|c|c|c|c|c|}
\hline Test \# & Sulfuric (M) & Oxalic (wt.\%) & Magnetite & Hematite & Boehmite & Gibbsite & HM Simulant & PUREX Simulant & Temperature $\left({ }^{\circ} \mathrm{C}\right)$ \\
\hline 1 & 0.05 & 1 & $\mathrm{~N}$ & $\mathrm{~N}$ & $\mathrm{~N}$ & $\mathrm{~N}$ & $\mathrm{~N}$ & $\mathrm{~N}$ & 45 \\
\hline 2 & 0.25 & 1 & $\mathrm{~N}$ & $\mathrm{~N}$ & $\mathrm{~N}$ & $\mathrm{~N}$ & $\mathrm{~N}$ & $\mathrm{~N}$ & 45 \\
\hline 3 & 0.05 & 1 & $\mathrm{~N}$ & $\mathrm{~N}$ & $\mathrm{~N}$ & $\mathrm{~N}$ & $\overline{\mathrm{N}}$ & $\overline{\mathrm{N}}$ & 75 \\
\hline 4 & 0.25 & 1 & $\mathrm{~N}$ & $\mathrm{~N}$ & $\mathrm{~N}$ & $\mathrm{~N}$ & $\mathrm{~N}$ & $\mathrm{~N}$ & 75 \\
\hline 5 & 0.05 & 1 & $\mathrm{Y}$ & $\mathrm{N}$ & $\mathrm{N}$ & $\mathrm{N}$ & $\mathrm{N}$ & $\mathrm{N}$ & 75 \\
\hline 6 & 0.05 & 1 & $\mathrm{~N}$ & $\mathrm{Y}$ & $\mathrm{N}$ & $\mathrm{N}$ & $\mathrm{N}$ & $\mathrm{N}$ & 75 \\
\hline 7 & 0.05 & 1 & $\mathrm{~N}$ & $\mathrm{~N}$ & $\bar{Y}$ & $\mathrm{~N}$ & $\overline{\mathrm{N}}$ & $\overline{\mathrm{N}}$ & 75 \\
\hline 8 & 0.05 & 1 & $\mathrm{~N}$ & $\mathrm{~N}$ & $\mathrm{~N}$ & $\bar{Y}$ & $\bar{N}$ & $\bar{N}$ & 75 \\
\hline 9 & 0.05 & 1 & $\mathrm{~N}$ & $\mathrm{~N}$ & $\mathrm{~N}$ & $\mathrm{~N}$ & $\bar{Y}$ & $\overline{\mathrm{N}}$ & 75 \\
\hline 10 & 0.05 & 1 & $\mathrm{~N}$ & $\mathrm{~N}$ & $\mathrm{~N}$ & $\mathrm{~N}$ & $\mathrm{~N}$ & $Y$ & 75 \\
\hline 11 & 0.25 & 1 & $\bar{Y}$ & $\mathrm{~N}$ & $\mathrm{~N}$ & $\mathrm{~N}$ & $\overline{\mathrm{N}}$ & $\overline{\mathrm{N}}$ & 45 \\
\hline 12 & 0.25 & 1 & $\mathrm{Y}$ & $\mathrm{N}$ & $\mathrm{N}$ & $\mathrm{N}$ & $\mathrm{N}$ & $\mathrm{N}$ & 75 \\
\hline 13 & 0.25 & 1 & $\mathrm{~N}$ & $\mathrm{Y}$ & $\mathrm{N}$ & $\mathrm{N}$ & $\mathrm{N}$ & $\mathrm{N}$ & 45 \\
\hline 14 & 0.25 & 1 & $\mathrm{~N}$ & $\bar{Y}$ & $\mathrm{~N}$ & $\mathrm{~N}$ & $\overline{\mathrm{N}}$ & $\overline{\mathrm{N}}$ & 75 \\
\hline 15 & 0.25 & 1 & $\mathrm{~N}$ & $\mathrm{~N}$ & $\mathrm{Y}$ & $\bar{N}$ & $\mathrm{~N}$ & $\mathrm{~N}$ & 45 \\
\hline 16 & 0.25 & 1 & $\mathrm{~N}$ & $\mathrm{~N}$ & $\bar{Y}$ & $\overline{\mathrm{N}}$ & $\overline{\mathrm{N}}$ & $\overline{\mathrm{N}}$ & 75 \\
\hline 17 & 0.25 & 1 & $\mathrm{~N}$ & $\mathrm{~N}$ & $\mathrm{~N}$ & $\mathrm{Y}$ & $\mathrm{N}$ & $\mathrm{N}$ & 45 \\
\hline 18 & 0.25 & 1 & $\mathrm{~N}$ & $\mathrm{~N}$ & $\mathrm{~N}$ & $Y$ & $\mathrm{~N}$ & $\mathrm{~N}$ & 75 \\
\hline 19 & 0.05 & 1 & $\mathrm{~N}$ & $\mathrm{~N}$ & $\mathrm{~N}$ & $\mathrm{~N}$ & $\mathrm{Y}$ & $\mathrm{N}$ & 45 \\
\hline 20 & 0.25 & 1 & $\mathrm{~N}$ & $\mathrm{~N}$ & $\mathrm{~N}$ & $\mathrm{~N}$ & $\mathrm{Y}$ & $\mathrm{N}$ & 75 \\
\hline 21 & 0.05 & 1 & $\mathrm{~N}$ & $\mathrm{~N}$ & $\mathrm{~N}$ & $\mathrm{~N}$ & $\mathrm{~N}$ & $\bar{Y}$ & 45 \\
\hline 22 & 0.25 & 1 & $\mathrm{~N}$ & $\mathrm{~N}$ & $\mathrm{~N}$ & $\mathrm{~N}$ & $\mathrm{~N}$ & $\mathrm{Y}$ & 75 \\
\hline
\end{tabular}

$\mathrm{N}$ : None

Y: Present 
The material tested was ASTM A285, Grade C carbon steel (UNS K02200). The chemical compositions (See Table 3-4) and the mechanical properties (see Table 3-5) of the asreceived coupons were vendor certified. This material was selected because it is representative of the Type I and II waste tanks in the liquid waste facility [17].

Table 3-4. Chemical Composition of A285 Grade C Carbon Steel (wt.\%)

\begin{tabular}{|c|c|c|c|c|c|c|c|c|}
\hline $\mathbf{C}$ & $\mathbf{M n}$ & $\mathbf{P}$ & $\mathbf{S}$ & $\mathbf{C u}$ & $\mathbf{N i}$ & $\mathbf{C r}$ & $\mathbf{S i}$ & $\mathbf{F e}$ \\
\hline 0.18 & 0.75 & 0.011 & 0.008 & 0.03 & 0.03 & 0.06 & - & balance \\
\hline
\end{tabular}

Table 3-5. Mechanical Properties of A285 Grade C Carbon Steel

\begin{tabular}{|c|c|c|}
\hline $\begin{array}{c}\text { Yield Strength } \\
\text { (ksi) }\end{array}$ & $\begin{array}{c}\text { Tensile Strength } \\
\text { (ksi) }\end{array}$ & \% Elongation \\
\hline 48 & 67 & $31(2$ inch $)$ \\
\hline
\end{tabular}

\subsection{ELECTROCHEMICAL CORROSION STUDIES}

\subsubsection{Corrosion Test Set-up}

Figure 3-1 shows the glass cell that was utilized for the corrosion testing. The working electrode was a carbon steel coupon that was embedded in an epoxy cold mount. The counter electrode was a stainless steel mesh shaped to form a cylinder that fits within the cell. The potential was measured with respect to saturated silver-silver chloride $(\mathrm{Ag} / \mathrm{AgCl})$ that acted as a reference electrode. These electrodes were connected to a Princeton Applied Research $^{\mathrm{TM}}$ (PAR) potentiostat that was controlled by CorrWare ${ }^{\mathrm{TM}}$ software, developed by SAI Associates. The test results were analyzed with the same software. The test temperature was maintained by a hot plate that had a temperature controller. Evaporation of the solution during testing was minimized with the use of a condenser. The glass cell was covered with insulation cloth during the test.

\subsubsection{Corrosion Test Methods}

The electrochemical tests performed include: 1) Open Circuit Potential (OCP), 2) Linear Polarization Resistance, 3) Cathodic Polarization, and 4) Cyclic Potentiodynamic Polarization. The OCP test reflects a measure of the electrochemical activity at the metal surface, i.e. whether it is actively corroding or becoming passive. This test also provides information on the relative stability of the passive film, and whether hydrogen evolution is thermodynamically possible. The effects of material (e.g., surface condition of coupon) and environmental variables (e.g., temperature, mixing, etc.) on these measurements were also investigated. 


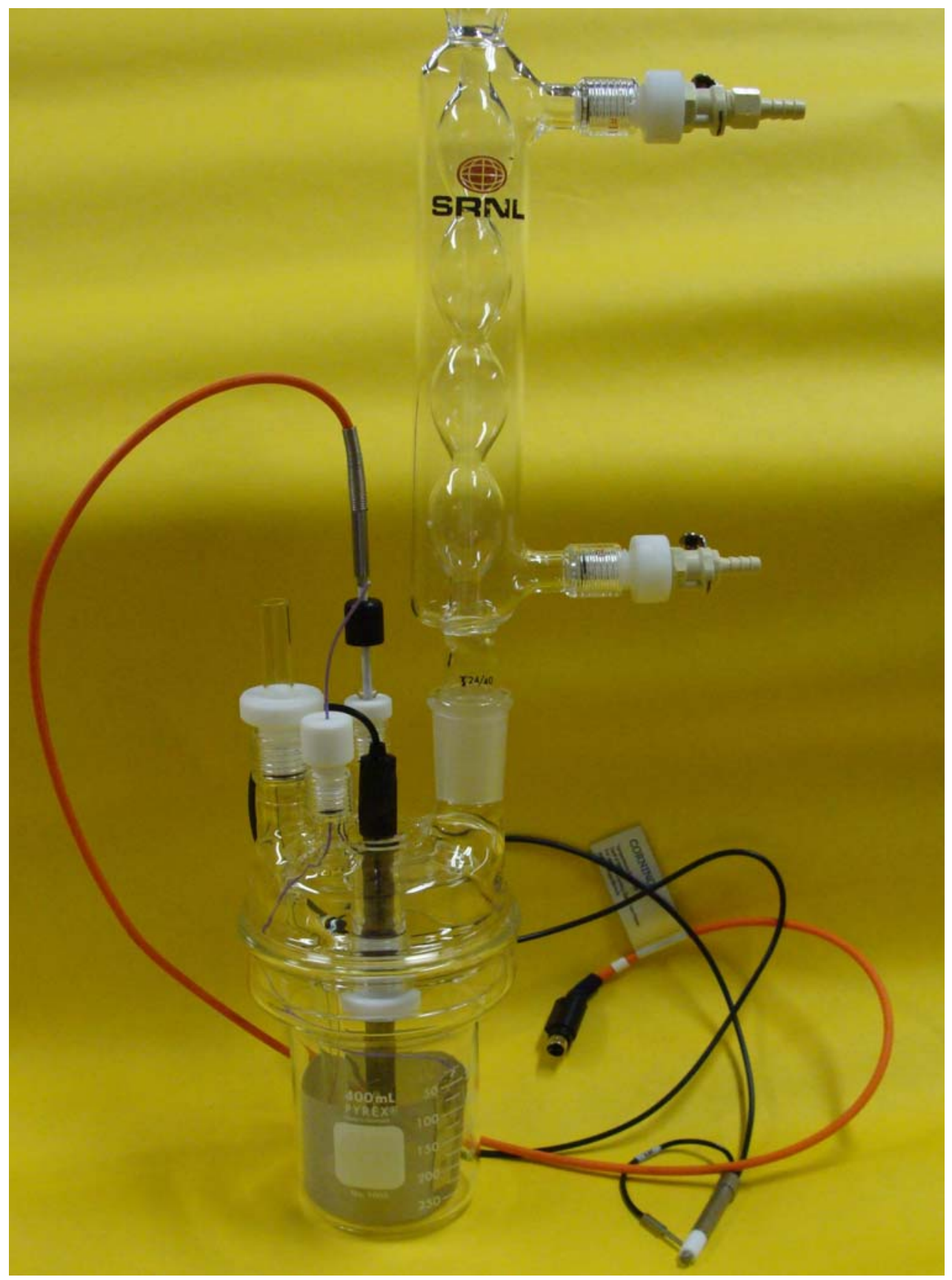

Figure 3-1. Electrochemical test set-up.

The propensity for hydrogen evolution may be visualized by analyzing the Pourbaix diagram for water, which is shown in Figure 3-2. The two parallel lines, identified as (a) and (b), define the region of stability of water as a function of potential and $\mathrm{pH}$. For potential and $\mathrm{pH}$ conditions between lines (a) and (b), water is thermodynamically stable. For any value of potential above line (b) water is thermodynamically unstable and oxygen is liberated, while at any conditions of potential and $\mathrm{pH}$ below line (a) water is thermodynamically unstable and 


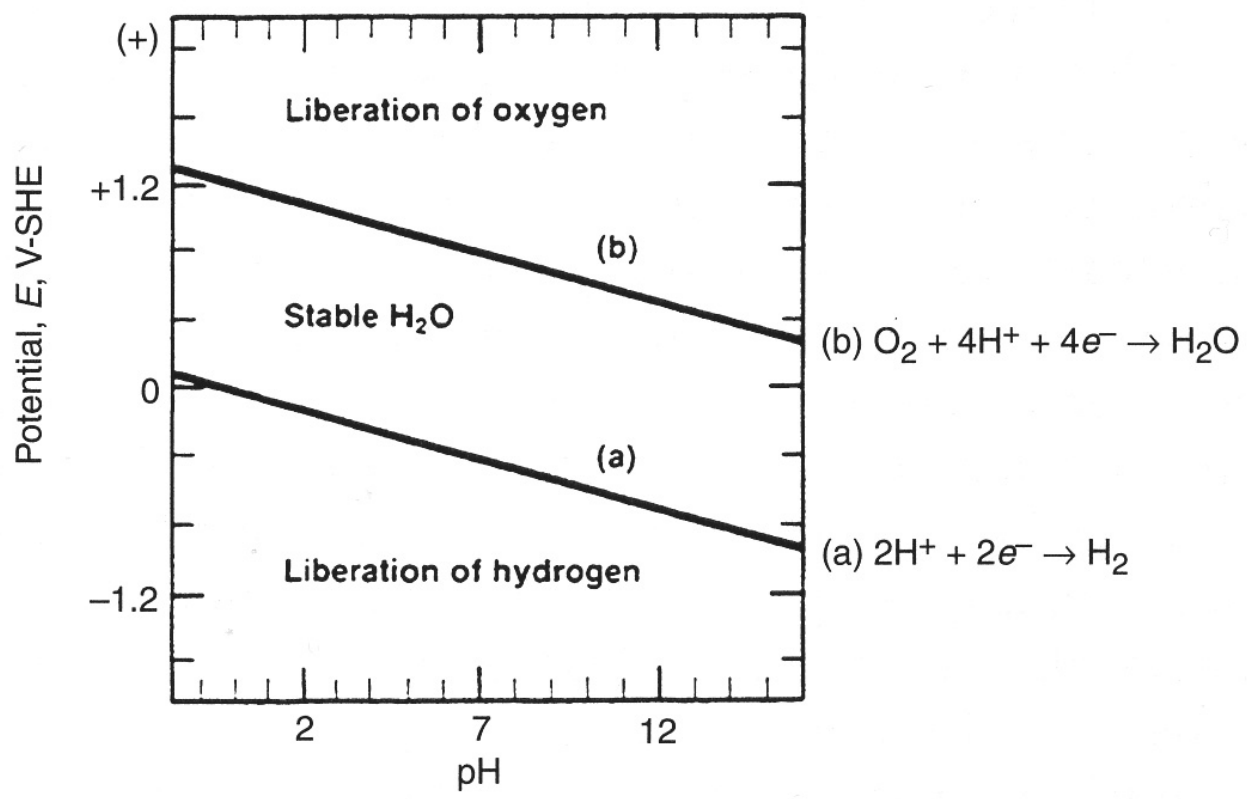

Figure 3-2. Pourbaix diagram for water [18].

hydrogen gas is generated. Therefore, from the measured potential and the $\mathrm{pH}$ values, it can be determined if it is thermodynamically possible for a corrosion reaction to generate hydrogen. If the measured OCP value from the test is below line (a), hydrogen evolution is possible.

The equation for line (a) is derived from the Nernst Equation:

$$
\mathrm{E}_{\mathrm{H} 2}=\mathrm{E}^{\circ}-2.303 \frac{R T}{F} * \mathrm{pH}
$$

where $\mathrm{E}^{\circ}$ is the standard potential for hydrogen $\left(\mathrm{E}^{\circ}=0.0 \mathrm{~V}\right), \mathrm{R}$ is the universal gas constant that equals to $1.99 \mathrm{cal} / \mathrm{mole}-\mathrm{K}, \mathrm{T}$ is the temperature in $\mathrm{K}$, and $\mathrm{F}$ is the Faraday constant equal that equals to 23,061 cal / V-equivalent. Thus, given the $\mathrm{pH}$ and temperature of the test, the potential below which hydrogen evolution would occur may be calculated. For these tests, the $\mathrm{pH}$ of each of the acid solutions was approximately 1 . From equation $3-1, \mathrm{E}_{\mathrm{H} 2}$ at $45^{\circ} \mathrm{C}$ is $-0.063 \mathrm{~V}$, while at $75^{\circ} \mathrm{C}$ it is $-0.069 \mathrm{~V}$. The potential utilized in the Nernst equation is with reference to the normal hydrogen electrode (NHE). Experimental measurements during these tests were made using a saturated $\mathrm{Ag} / \mathrm{AgCl}$ reference electrode. To convert the potentials that are referenced to the hydrogen potential to one with reference to the $\mathrm{Ag} / \mathrm{AgCl}$, subtract $197 \mathrm{mV}$. The OCP values measured during the electrochemical tests were compared to these values to determine if hydrogen evolution is thermodynamically possible.

The Linear Polarization Resistance (LPR) technique provides a quick, non-destructive, in situ estimate of the uniform or general corrosion rate. An ASTM standard practice was utilized to conduct the LPR test [19]. This technique is based on an observation that when the potential at the metal surface is polarized anodically or cathodically within $15 \mathrm{mV}$ of the 
OCP, the measured current density at the metal surface increases linearly with the potential. The slope of this line is defined as the polarization resistance $\left(\mathrm{R}_{\mathrm{p}}\right)$. Stern and Geary modified the fundamental equation for electrochemical reaction kinetics [20], and demonstrated that the relationship between the corrosion current density ( $i_{\text {corr }}$ ) and $R_{p}$ at the OCP can be given by Equation 3-2.

$$
\mathrm{i}_{\text {corr }}=\frac{\beta_{a} \beta_{c}}{2.3\left(\beta_{a}+\beta_{c}\right) R_{p}}
$$

where $\beta_{\mathrm{a}}$ and $\beta_{\mathrm{c}}$ are the anodic and cathodic Tafel slopes, respectively. The Tafel slope was determined experimentally, which will be discussed in the subsequent section on the cathodic polarization tests. If the Tafel slopes are unknown, frequently the assumed value for $\beta_{\mathrm{a}}$ and $\beta_{\mathrm{c}}$ is $0.120 \mathrm{~V} /$ decade. Unless the actual slopes are quite different from $0.120 \mathrm{~V} / \mathrm{decade}$, the error in the value of the corrosion current $\left(\mathrm{i}_{\text {corr }}\right)$ is not significant. The software package for the potentiostats utilized the $0.120 \mathrm{~V} /$ decade assumption to calculate $i_{\text {corr. }}$. This assumption and its impact on the corrosion rate calculations were investigated during the cathodic polarization studies discussed in the next section. The $i_{\text {corr }}$ is related to the corrosion rate (CR) by the following equation:

$$
\mathrm{CR}=0.13 * \frac{i_{c o r r} E_{w}}{\rho}
$$

where $E_{w}$ is the equivalent weight of iron (27.9 g/equivalent), and $\rho$ is the density of iron $\left(7.86 \mathrm{~g} / \mathrm{cm}^{3}\right)$. The corrosion rate is generally reported in terms of mils $(0.001$ inches $)$ per year.

The potential scan rate is a critical variable for the LPR technique [21]. A test performed at too high of a scan rate causes a high capacitive current that results in hysteresis in the plot of potential versus current. As a result, the polarization resistance may be under-estimated and the corrosion rate, which is inversely proportional to the polarization resistance, may be overestimated. On the other hand faster scan rates are desirable since the time at which the specimen is polarized from its equilibrium potential is minimized. An optimum scan rate of $0.167 \mathrm{mV} / \mathrm{s}$ was selected for these tests. Figure 3-3 shows an example of an LPR curve.

Cathodic polarization (CP) studies were utilized to investigate the kinetics of the cathodic reaction. Based on these studies, it can be determined if there is a propensity for hydrogen evolution. The cathodic polarization test sequentially scans the potential of the working electrode toward more negative potentials with respect to OCP in a controlled manner. Although there is no standard practice for this test, it has long been utilized to probe the kinetics of not only the cathodic reaction but the corrosion rate as well [22]. At potentials relatively close to the $\mathrm{OCP}$, the relationship between the potential and the current is given by the Tafel expression [23] identified by Equation 3-4.

$$
\eta=\beta \log \left(\mathrm{i} / \mathrm{i}_{0}\right)
$$




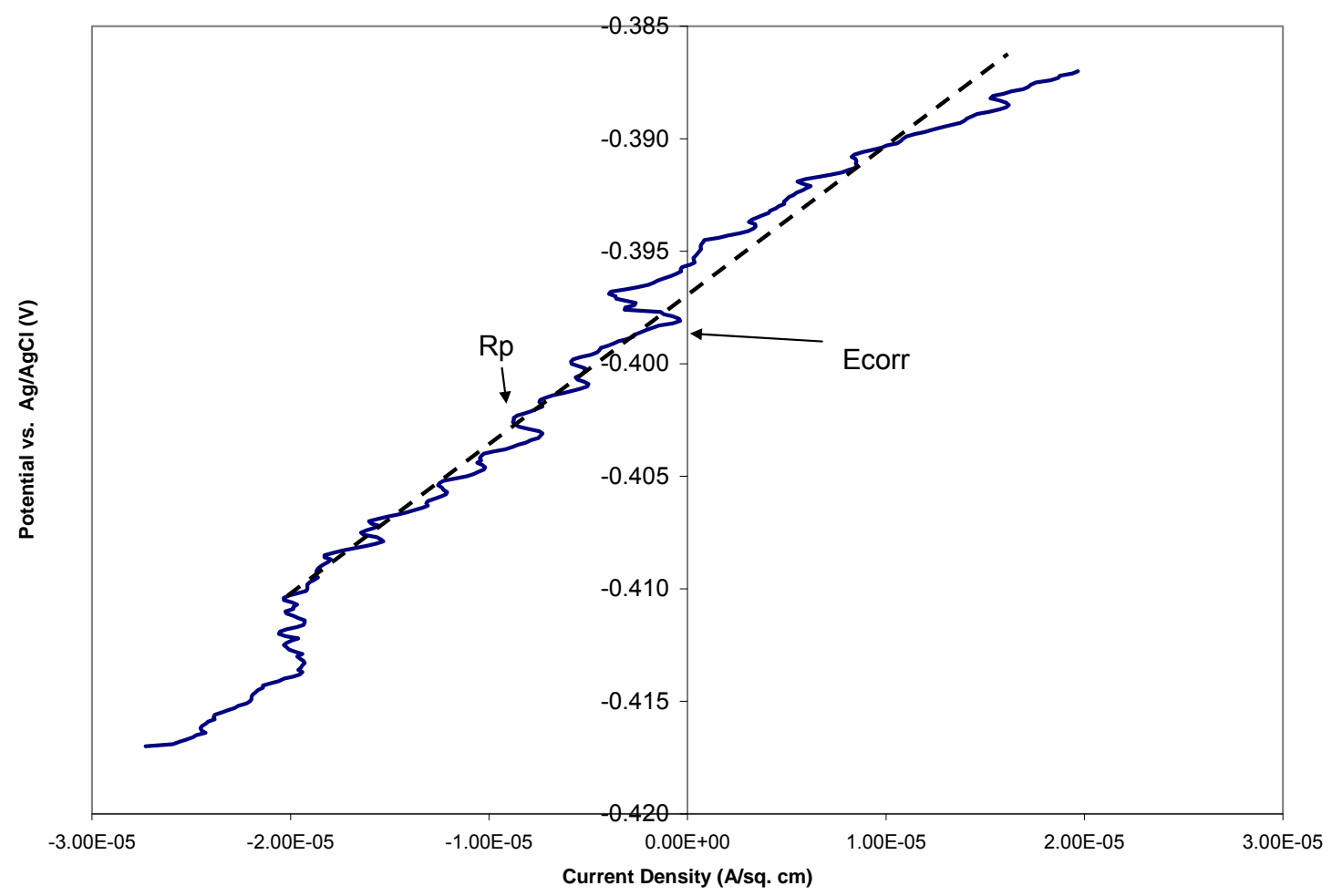

Figure 3-3. Example of Linear Polarization Resistance curve measured during tests.

where $\eta$ is the overvoltage, defined as E- OCP, in volts; $\beta$ is the slope of the line on the potential-log current density plot, also known as the cathodic Tafel slope in volts/decade of current; $i$ is the measured current density at the applied potential $\mathrm{E}$ in $\mathrm{A} / \mathrm{sq} . \mathrm{cm}$; and $\mathrm{i}_{0}$ is the exchange current density, in $\mathrm{A} / \mathrm{sq}$. $\mathrm{cm}$, which represents the equal current density for the forward and reverse reactions at the electrode at equilibrium.

Figure 3-4 shows $\eta$ vs. log current density plots from cathodic polarization tests. This figure illustrates how $\eta$ and $i_{0}$ are determined. The Tafel equation is obeyed within the region of applied current density, i, below the limiting current density for concentration polarization, and above the exchange current density. The cathodic Tafel slope is typically determined by finding the linear portion of the curve at current densities between $2 \times 10^{-5}$ and $1 \times 10^{-3} \mathrm{~A} / \mathrm{sq}$. $\mathrm{cm}$ [23]. In the case of the $1 \mathrm{wt} . \%$ oxalic acid solution the slope, was $1 \times 10^{-3} \mathrm{~A} / \mathrm{cm}^{2}$. However, for the HM and PUREX solutions, the current density was less than $1 \times 10^{-3} \mathrm{~A} / \mathrm{cm}^{2}$ and thus, the linear portion of the lines were fitted to determine $\eta$. The exchange current density was determined by extrapolating the Tafel slope line until it intersects the line at $\eta=$ 0 (Figure 3-12).

The dominant term controlling the corrosion rate in many metals exposed to non-oxidizing acids, such as oxalic acid, is hydrogen overvoltage at cathodic areas of the metal. Hydrogen overvoltage is the difference of potential between a cathode at which hydrogen is being 
evolved, and a hydrogen electrode at equilibrium in the same solution. To determine if hydrogen is the cathodic reaction the following relationship is utilized:

$$
\alpha=2.3 \mathrm{R} \mathrm{T} /(\beta \mathrm{F})
$$

where $\alpha$ is the transfer coefficient, $\mathrm{R}$ is the universal gas constant equal to $1.99 \mathrm{cal} / \mathrm{mole}-\mathrm{K}, \mathrm{T}$ is the temperature in $\mathrm{K}$, and $\mathrm{F}$ is the Faraday constant equal to 23,061 cal /V-equivalent. For iron and steel, the value of $\alpha$ lies between 0.4 and 0.6 if the hydrogen reaction is occurring.

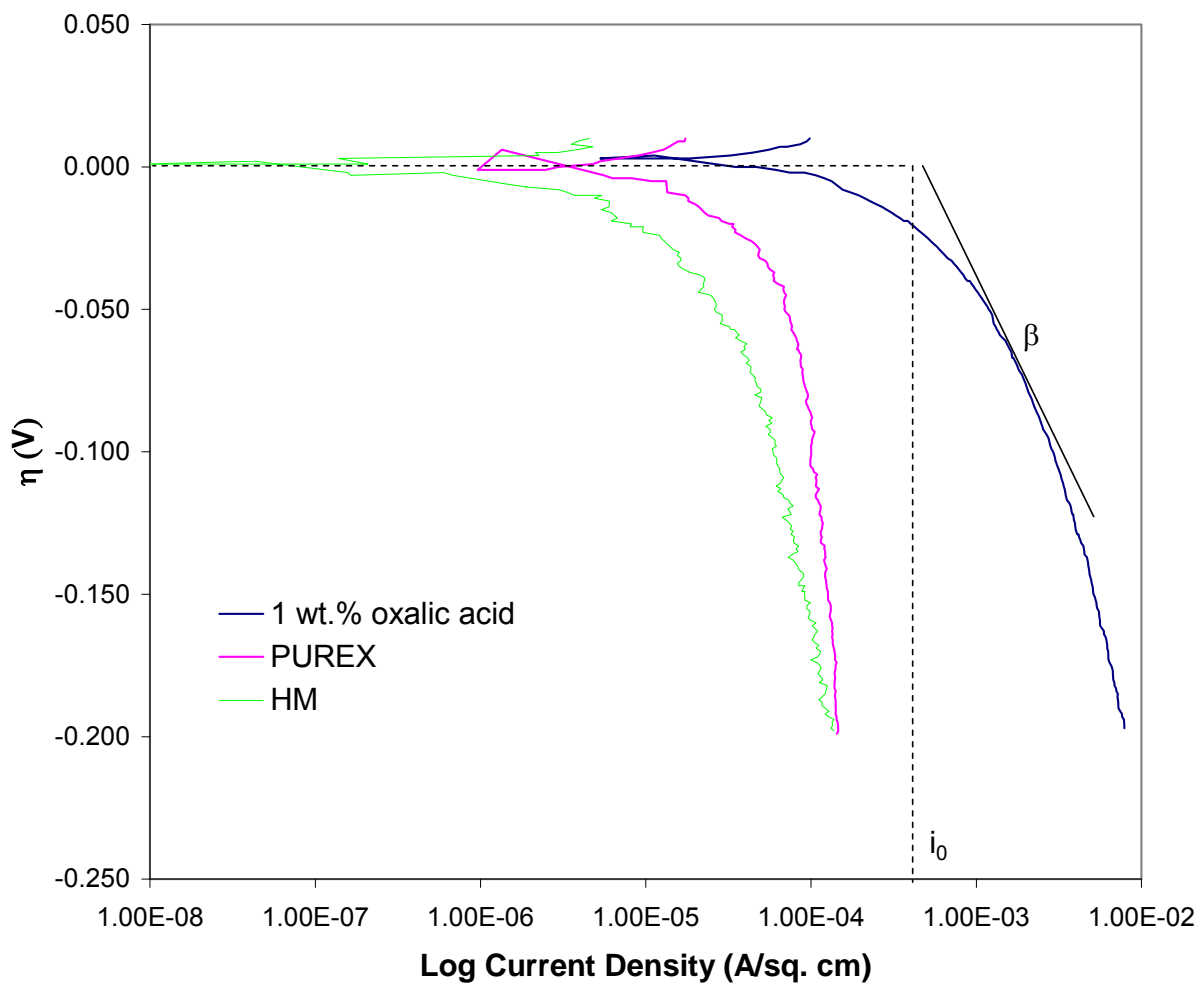

Figure 3-4. Examples of Cathodic Polarization curves.

The Cyclic Potentiodynamic Polarization (CPP) tests were conducted to examine the stability of any passivating oxide or oxalate phases. The CPP tests are useful for investigating the vulnerability of a material to localized corrosion such as stress corrosion cracking and/or pitting. As a result, the protective or inhibitive capabilities of the oxalate film can be determined. For this test, a sample is exposed to the solution of interest and allowed to reach equilibrium. This test is initiated at a potential $50 \mathrm{mV}$ negative with respect to the OCP. A sequentially increasing potential is then applied to the sample. The resultant current due to the change in potential is measured to establish a current-potential relationship. An example of this relationship is shown in Figure 3-5.

Various current responses that occur during the forward scan have been shown to be indicative of localized corrosion susceptibility. In particular, the breakdown potential, $\mathrm{E}_{\mathrm{b}}$, is the potential where the current increases rapidly with a small change in potential. This change has been correlated with a reduction in the passive nature of the material. The 
passive to active transition region, shown in Figure 3-5 is the region in which the material is susceptible to localized corrosion. The smaller the difference between values of OCP and $\mathrm{E}_{\mathrm{b}}$,

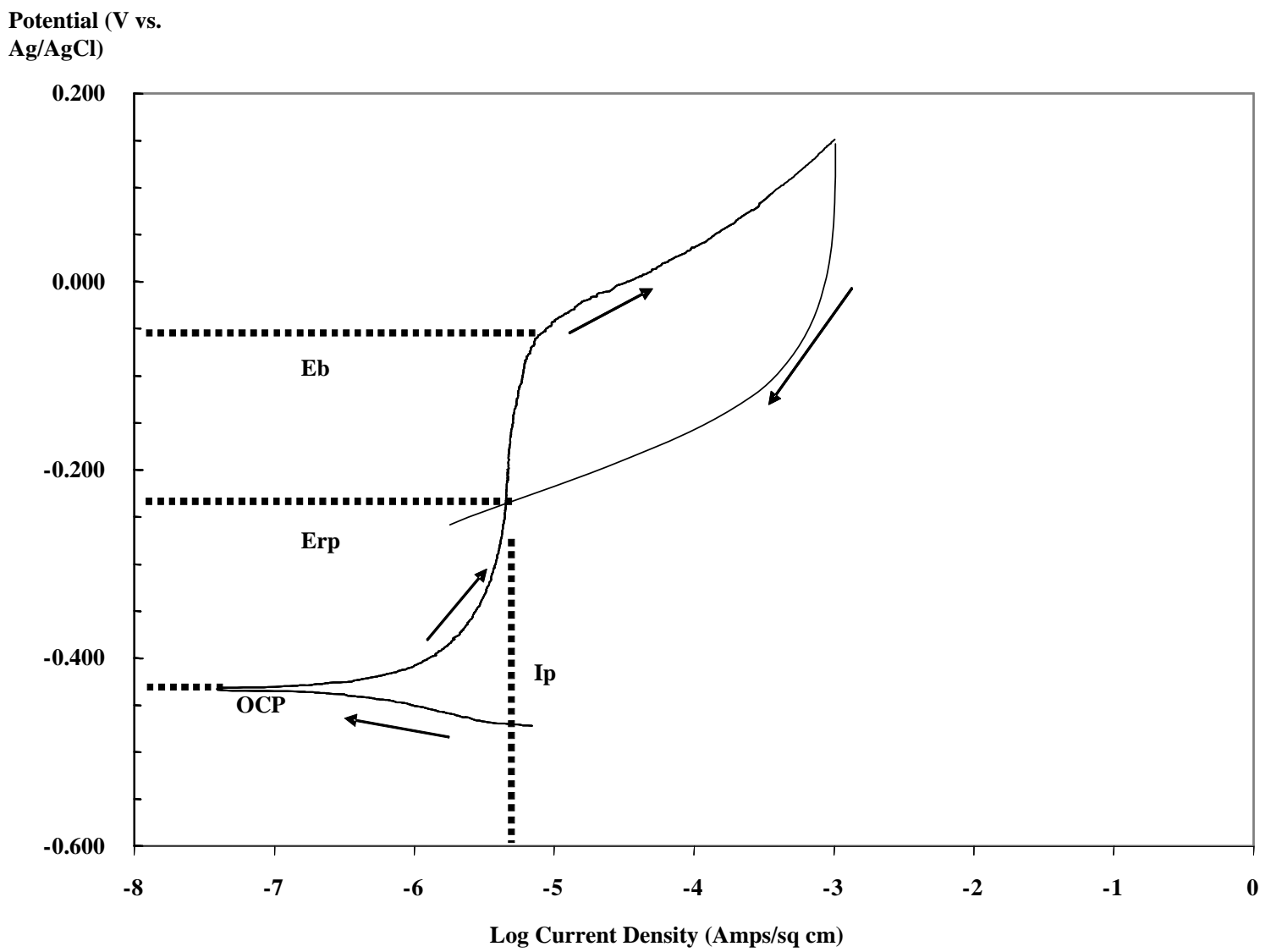

Figure 3-5. Plot of schematic CPP data showing characteristic potentials and currents.

the more susceptible the material is to localized corrosion in that environment. The passive current density, $\mathrm{I}_{\mathrm{p}}$, is also indicative of the protective nature of the oxide film, or in this case the oxalate film. Lower passive current densities are indicative of a more protective surface film.

Data from the reverse scan as well as the forward scan are utilized for this purpose. The additional parameters that were evaluated included the repassivation potential, $\mathrm{E}_{\mathrm{rp}}$ and the observation of positive or negative hysteresis on the reverse scan. The following guidelines were also utilized to examine the CPP scans [24]:

- The differences of $E_{b}$ and $E_{r p}$ with respect to OCP are a measure of the susceptibility of a material to localized attack in a given environment. When comparing a materials behavior in different environments, a larger difference indicates greater resistance to localized corrosion. 
- If $E_{\mathrm{rp}}$ is more negative than OCP, or if $\mathrm{E}_{\mathrm{rp}}$ is less than $200 \mathrm{mV}$ more positive than $\mathrm{E}_{\text {corr, }}$ the material is susceptible to crevice corrosion in the environment. This guideline makes allowances for variability in the measurement of these potentials.

- If the current density of the reverse scan is greater than that for the forward scan, localized corrosion is likely. This behavior is known as negative hysteresis.

- If the current density of the reverse scan is less than that for the forward scan, passive behavior is expected. This behavior is known as positive hysteresis.

\subsection{EXPERIMENTAL RESULTS}

\subsection{OPEN CIRCUIT POTENTIAL (OCP) RESULTS}

Tables 4-1 and 4-2 show the stable OCP results for the 44 tests conducted. A stable OCP is achieved when the potential remains constant (i.e., less than $5 \mathrm{mV}$ change) over a 30-60 minute time frame. For these tests, the time needed to achieve a constant potential was between 30 and 90 minutes. In general, the reagents with the hematite and magnetite pure oxide phases required the longest time to reach a stable potential. A single potential was reported if the OCPs for duplicate tests were within $\pm 10 \mathrm{mV}$. In this case, an average value was reported. If the difference in the OCP values was greater than $\pm 10 \mathrm{mV}$, both values were reported. Greater divergence in the OCPs for the duplicate tests was observed for the sulfuric acid based reagents, with the magnetite and hematite oxide phases exhibiting the greatest difference. In many cases, the stable OCP was lower than $\mathrm{E}_{\mathrm{H} 2}$ (i.e., $-0.266 \mathrm{~V}$ vs. $\mathrm{Ag} / \mathrm{AgCl}$ ), which suggests a propensity for hydrogen evolution. A closer examination of the effects of the process variables on the OCP was performed to investigate the conditions that may be of the greatest concern.

Figure 4-1 shows the OCP results for the nitric and sulfuric acid reagents. This particular test was conducted in the low temperature, low concentration environment. Both reagents exhibited a stable OCP that was lower than $\mathrm{E}_{\mathrm{H} 2}$. The OCP for the nitric acid based reagent was at a more noble (i.e., more positive value) potential compared to that of the sulfuric acid based reagent. This result was expected given that nitric acid is an oxidizing acid.

Figures 4-2 and 4-3 show the OCP results for the nitric and sulfuric acid reagents, respectively, after they have been equilibrated with the pure oxide phases. These particular tests were conducted in the high temperature, low concentration environment. For the nitric acid reagent tests, all samples exhibited a stable OCP that was active (i.e., more negative) with respect to $\mathrm{E}_{\mathrm{H} 2}$, although OCPs for the reagents with magnetite and hematite were very close to this value.

The OCP values for the iron oxide phases, magnetite and hematite, were noble compared to the OCP values for the reagent alone. Typically, a shift such as this would indicate that the formation of a passive layer is occurring. An increase in the ferrous ion concentration could be the cause of this potential shift. The OCPs for these iron oxide phases also showed some degree of instability (i.e., noise), which suggests that if a film is forming, it is not very stable or may not be very protective. 
Table 4-1. Open Circuit Potential Results for Sulfuric/Oxalic Acid Solutions

\begin{tabular}{|c|c|c|c|c|c||}
\hline Test ID & $\begin{array}{c}\text { Sulfuric } \\
\text { Acid (M) }\end{array}$ & $\begin{array}{c}\text { Oxalic } \\
\text { Acid } \\
\text { (wt. } \%)\end{array}$ & $\begin{array}{c}\text { Temperature } \\
\mathbf{(}{ }^{\mathbf{C}} \text { ) }\end{array}$ & $\begin{array}{c}\text { Oxide or } \\
\text { Simulant }\end{array}$ & $\begin{array}{c}\text { Stable Open Circuit } \\
\text { Potential (V vs. } \\
\text { Ag/AgCl) }\end{array}$ \\
\hline \hline 1 & 0.05 & 1 & 45 & None & -0.470 \\
\hline 2 & 0.25 & 1 & 45 & None & -0.471 \\
\hline 3 & 0.05 & 1 & 75 & None & -0.458 \\
\hline 4 & 0.25 & 1 & 75 & None & -0.445 \\
\hline 5 & 0.05 & 1 & 75 & Magnetite & -0.2 to 0.041 \\
\hline 6 & 0.05 & 1 & 75 & Hematite & -0.205 to -0.118 \\
\hline 7 & 0.05 & 1 & 75 & Boehmite & -0.482 \\
\hline 8 & 0.05 & 1 & 75 & Gibbsite & -0.595 \\
\hline 9 & 0.05 & 1 & 75 & HM & -0.126 \\
\hline 10 & 0.05 & 1 & 75 & PUREX & -0.159 to -0.141 \\
\hline 11 & 0.25 & 1 & 45 & Magnetite & -0.119 \\
\hline 12 & 0.25 & 1 & 75 & Magnetite & -0.5 to -0.424 \\
\hline 13 & 0.25 & 1 & 45 & Hematite & -0.291 to -0.152 \\
\hline 14 & 0.25 & 1 & 75 & Hematite & -0.142 to -0.124 \\
\hline 15 & 0.25 & 1 & 45 & Boehmite & -0.455 \\
\hline 16 & 0.25 & 1 & 75 & Boehmite & -0.509 to -0.458 \\
\hline 17 & 0.25 & 1 & 45 & Gibbsite & -0.496 to -0.324 \\
\hline 18 & 0.25 & 1 & 75 & Gibbsite & -0.549 to -0.512 \\
\hline 19 & 0.05 & 1 & 45 & HM & -0.459 \\
\hline 20 & 0.25 & 1 & 75 & HM & -0.422 \\
\hline 21 & 0.05 & 1 & 45 & PUREX & -0.193 to -0.165 \\
\hline 22 & 0.25 & 1 & 75 & PUREX & -0.109 to -0.074 \\
\hline \hline
\end{tabular}


Table 4-2. Open Circuit Potential Results for Nitric/Oxalic Acid Solutions

\begin{tabular}{|c|c|c|c|c|c||}
\hline Test ID & $\begin{array}{c}\text { Nitric Acid } \\
(\mathbf{M})\end{array}$ & $\begin{array}{c}\text { Oxalic } \\
\text { Acid } \\
\text { (wt. } \%)\end{array}$ & $\begin{array}{c}\text { Temperature } \\
\left({ }^{\circ} \mathbf{C}\right)\end{array}$ & $\begin{array}{c}\text { Oxide or } \\
\text { Simulant }\end{array}$ & $\begin{array}{c}\text { Stable Open } \\
\text { Circuit Potential } \\
\text { (V vs. Ag/AgCl) }\end{array}$ \\
\hline \hline 1 & 0.1 & 1 & 45 & None & -0.358 \\
\hline 2 & 0.5 & 1 & 45 & None & -0.407 to -0.391 \\
\hline 3 & 0.1 & 1 & 75 & None & -0.357 \\
\hline 4 & 0.5 & 1 & 75 & None & -0.375 to -0.332 \\
\hline 5 & 0.1 & 1 & 75 & Magnetite & -0.265 \\
\hline 6 & 0.1 & 1 & 75 & Hematite & -0.28 \\
\hline 7 & 0.1 & 1 & 75 & Boehmite & -0.373 to -0.356 \\
\hline 8 & 0.1 & 1 & 75 & Gibbsite & -0.375 to -0.332 \\
\hline 9 & 0.1 & 1 & 75 & HM & -0.478 \\
\hline 10 & 0.1 & 1 & 75 & PUREX & -0.324 to -0.298 \\
\hline 11 & 0.5 & 1 & 45 & Magnetite & -0.202 \\
\hline 12 & 0.5 & 1 & 75 & Magnetite & -0.336 to -0.301 \\
\hline 13 & 0.5 & 1 & 45 & Hematite & -0.297 to -0.257 \\
\hline 14 & 0.5 & 1 & 75 & Hematite & -0.198 to -0.180 \\
\hline 15 & 0.5 & 1 & 45 & Boehmite & -0.402 to -0.370 \\
\hline 16 & 0.5 & 1 & 75 & Boehmite & -0.37 to -0.224 \\
\hline 17 & 0.5 & 1 & 45 & Gibbsite & -0.415 to -0.31 \\
\hline 18 & 0.5 & 1 & 75 & Gibbsite & -0.439 \\
\hline 19 & 0.1 & 1 & 45 & HM & -0.166 \\
\hline 20 & 0.5 & 1 & 75 & HM & -0.408 to -0.382 \\
\hline 21 & 0.1 & 1 & 45 & PUREX & -0.292 \\
\hline 22 & 0.5 & 1 & 75 & PUREX & -0.394 to -0.339 \\
\hline
\end{tabular}

On the other hand, the OCP values for the aluminum oxide phases, boehmite and gibbsite, were active to the OCP values for the reagent alone. A shift such as this would indicate that a passive film is less likely to form. Thus, general corrosion would be anticipated.

For the sulfuric acid reagent tests shown in Figure 4-3, the OCP values for the reagents with magnetite and hematite were noble to $\mathrm{E}_{\mathrm{H} 2}$, while the OCPs for the reagents with boehmite and gibbsite were active with respect to this value. The OCPs for the iron oxide phases were noble to the OCP for the reagent alone. Typically a shift such as this would indicate that the formation of a passive layer is occurring. An increase in the ferrous ion concentration could be the cause of this potential shift. A comparison of these data with those shown in Figure 4-2, further suggests that a greater concentration of ferrous ions may be present in the sulfuric acid based reagent than in the nitric acid based reagent. The OCPs for these iron oxide phases also showed some degree of instability (i.e., noise), which suggests that even if a film is forming, it is not very stable or may not be very protective. 
SRNL-STI-2010-00555, REV. 0

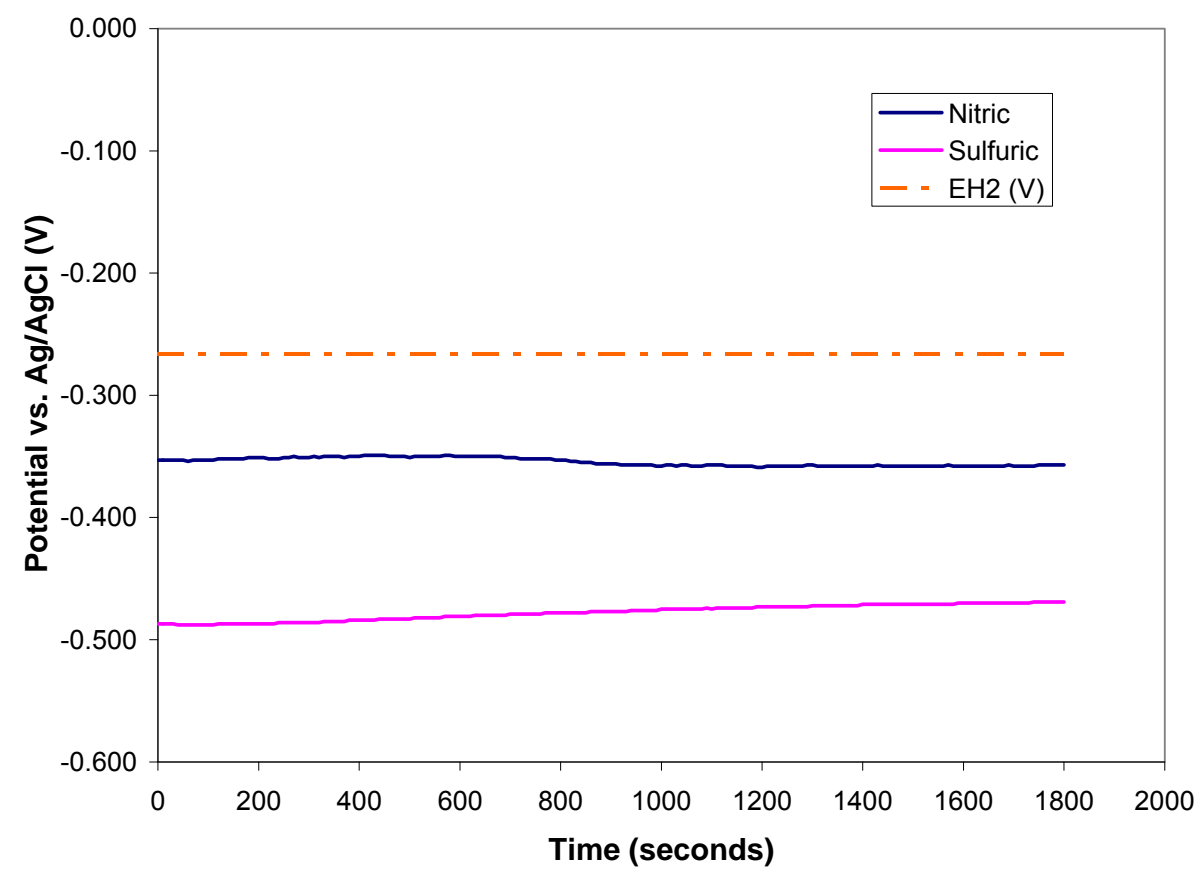

Figure 4-1. OCP results for $0.1 \mathrm{M}$ nitric and $0.05 \mathrm{M}$ sulfuric acid reagents at $45^{\circ} \mathrm{C}$.

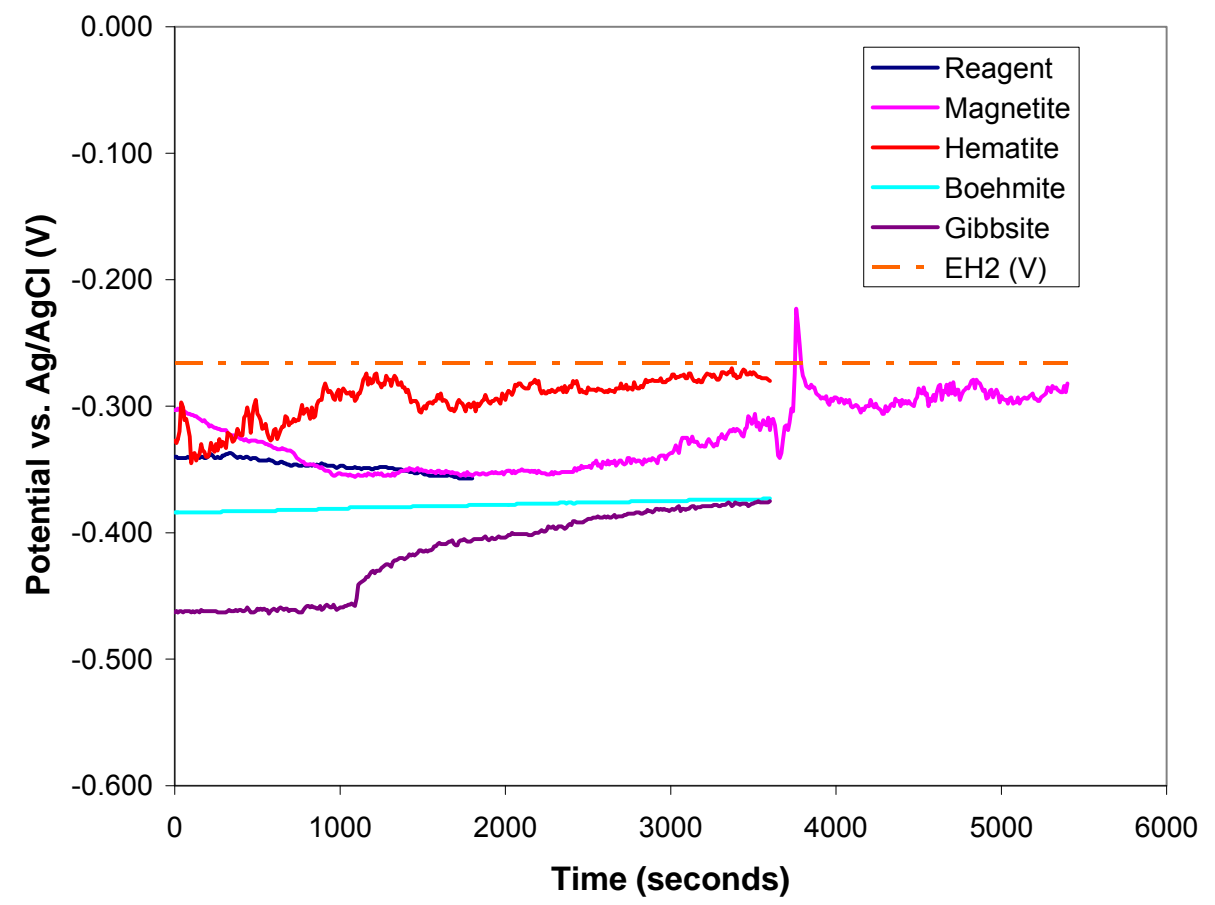

Figure 4-2. OCP results for $0.1 \mathrm{M}$ nitric acid with pure oxide phases at $75^{\circ} \mathrm{C}$. 


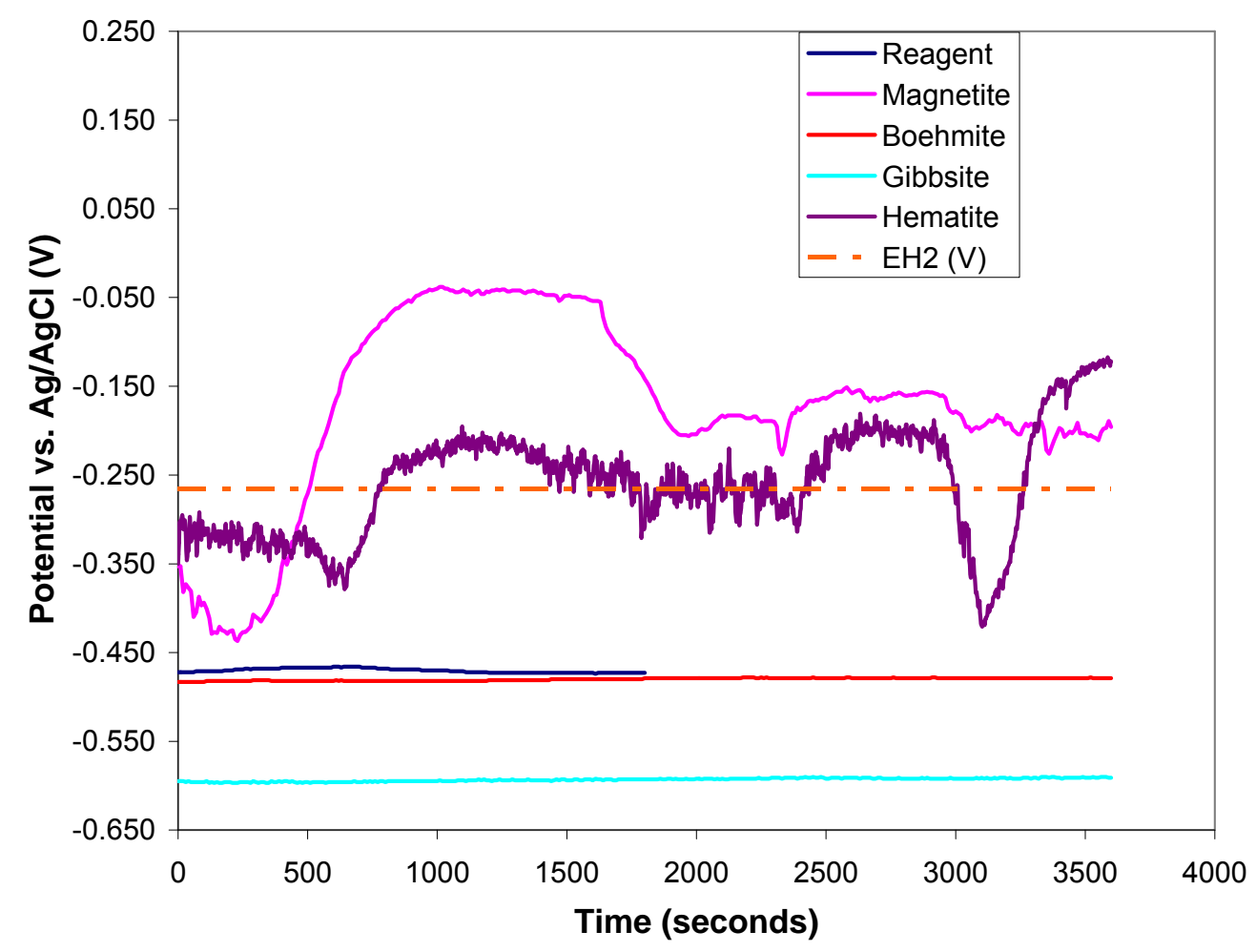

Figure 4-3. OCP results for $0.05 \mathrm{M}$ sulfuric acid with pure oxide phases at $75^{\circ} \mathrm{C}$.

The OCP for the sulfuric acid reagent with the gibbsite aluminum oxide phase was very active with respect to the OCP for the reagent alone. Such a shift would indicate that a passive film is less likely to form. Thus, general corrosion would be anticipated. The OCP for the boehmite oxide phase was essentially the same as the OCP for the reagent, most likely due to poor boehmite dissolution. Thus, from a corrosion perspective, the behavior should be very similar (i.e., general corrosion).

Figures 4-4 and 4-5 show the OCP results for the nitric and sulfuric acid reagents, respectively, after they have been equilibrated with the PUREX and HM sludge simulants. These particular tests were conducted in the high temperature, high concentration environment. For the nitric acid based reagent tests, shown in Figure 4-4, all OCP values exhibited a stable OCP that was active with respect to $\mathrm{E}_{\mathrm{H} 2}$.

The OCP for both sludge simulants in the nitric acid based reagent was essentially the same as the OCP for the reagent alone. Therefore, similar general corrosion behavior would be anticipated. The OCP for the sludge simulants in the sulfuric acid based reagent were significantly different from the OCP for the reagent alone. The OCP for PUREX exhibited a stable OCP that was noble with respect to $\mathrm{E}_{\mathrm{H} 2}$, while the OCP for $\mathrm{HM}$ was active. The OCP for the PUREX simulant in the sulfuric acid reagent, which contains primarily iron oxides, was noble to the OCP for the reagent alone. Typically, such a shift would indicate that the formation of a passive layer is occurring. The formation of a passive layer is consistent with 
the lower corrosion rate for the PUREX sludge simulant compared to those with the reagent and the other oxides (see Linear Polarization Test Results).

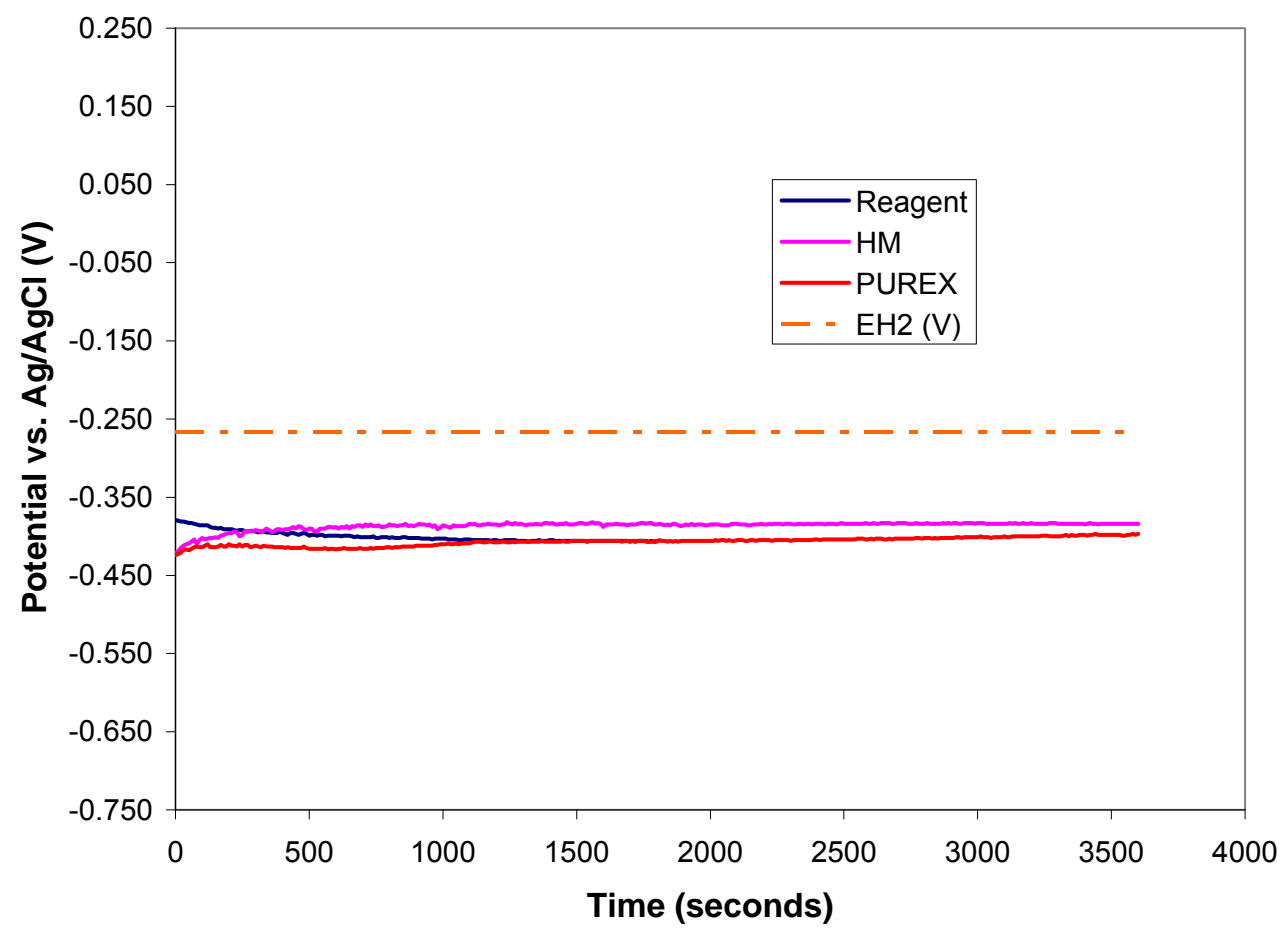

Figure 4-4. OCP results for $0.5 \mathrm{M}$ nitric acid with sludge simulants at $75{ }^{\circ} \mathrm{C}$.

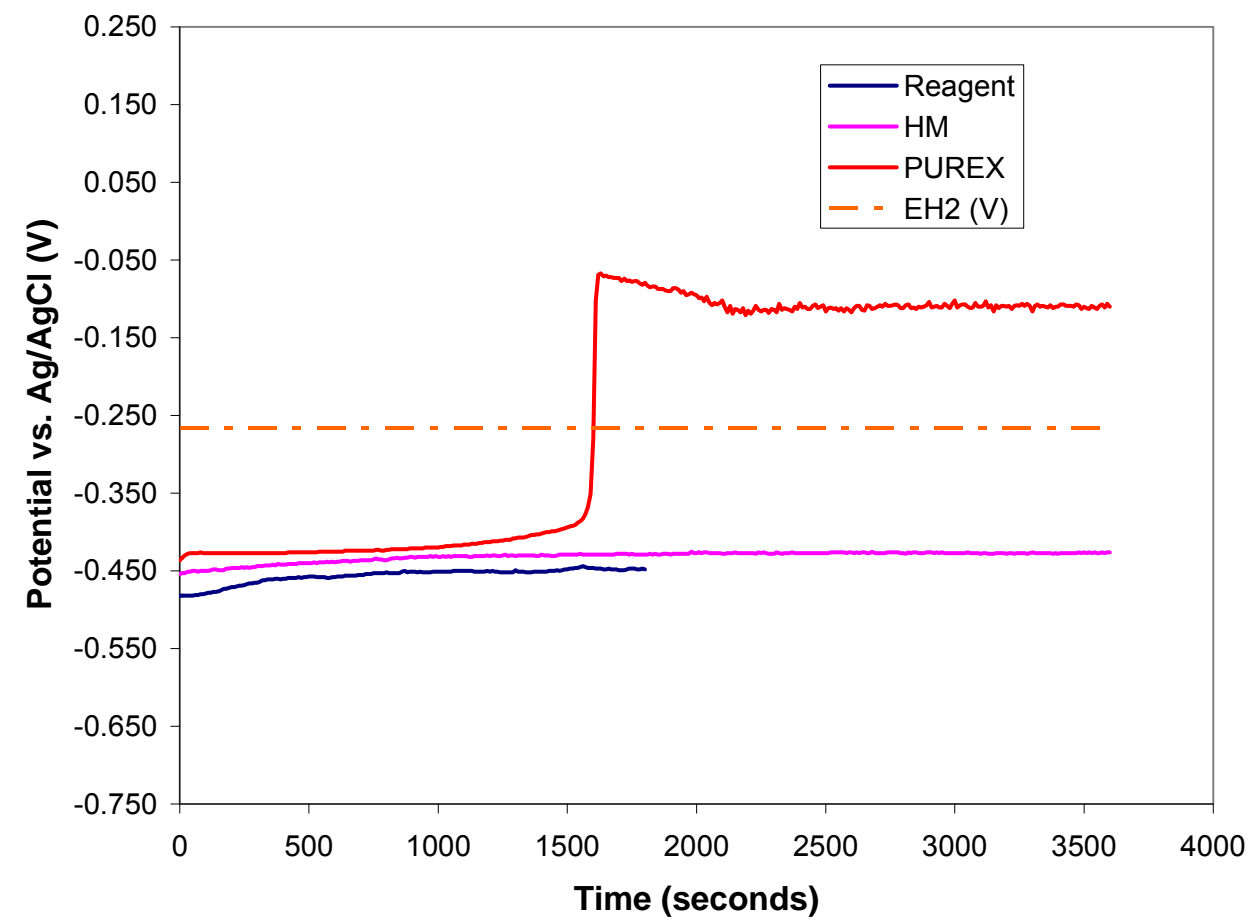

Figure 4-5. OCP results for $0.25 \mathrm{M}$ sulfuric acid with sludge simulants at $75^{\circ} \mathrm{C}$. 
On the other hand, OCP for the HM sludge simulant in the sulfuric acid reagent is only slightly noble with respect to that of the reagent alone. The presence of a greater concentration of aluminum phases within this sludge simulant may explain this more active OCP. Thus, a higher general corrosion rate would be anticipated for the PUREX solution.

\subsection{LINEAR POLARIZATION RESISTANCE RESULTS}

The results of the Linear Polarization Resistance tests are shown in Tables 4-3 and 4-4. The general corrosion rates are an average of two tests. The range of corrosion rates for the sulfuric acid/oxalic acid reagent only tests (Table 4-3, Tests 1 through 4) was 138 to 2031 mpy, while for the nitric acid/oxalic acid reagent only tests (Table 4-4, Tests 1 through 4) the range was 54 to $1848 \mathrm{mpy}$. Thus, for both reagents the corrosion rate increased significantly with temperature and concentration. These tables also show the effect of the addition of the pure phase oxide or sludge solids on the corrosion rate. For the sulfuric acid/oxalic acid reagent with solids tests (Table 4-3, Tests 5 through 22) the corrosion rate ranged between 13 to $1335 \mathrm{mpy}$, while for the nitric acid/oxalic acid reagent with solids tests (Table 4-4, Tests 5 through 22) the corrosion rate ranged between 54 and 4313 mpy. As with the tests in the reagents, the corrosion rates increased significantly with temperature and concentration.

In general these corrosion rates are greater than those observed for tests that were performed in 1 wt.\% [14] and 8 wt.\% oxalic acid [10] solutions, which were less than 25 mpy and 60 mpy, respectively. For a reagent to be considered for use in an actual waste tank, corrosion rates less than $150 \mathrm{mpy}$ are desirable. If the chemical cleaning process were to be performed for one month, this corrosion rate would result in a wall thickness loss of 12.5 mils. This wall thickness loss is approximately the same as that observed during recent chemical cleaning operations in Tank 6 , which utilized $8 \mathrm{wt} . \%$ oxalic acid [25]. It should be noted that in the latter case, multiple strikes with the $8 \mathrm{wt} . \%$ oxalic acid were performed over a period of several months.

For evaluation purposes, the effect of each of the solids phases on the corrosion rate was investigated for various combinations of reagent concentration and temperature. Figures 4-6 through 4-9 show the results for the nitric acid based reagents, while Figures 4-10 through 413 are the results for the sulfuric acid based reagents. Figure 4-6 shows the corrosion rates for the high temperature, high concentration nitric acid based reagent. The corrosion rates ranged between 999 and 4313 mpy. Except for the case of the HM sludge simulant solids, the corrosion rates for the tests with solids were less than or equal to the corrosion rate with reagent alone. The reduction in general corrosion rate with the addition of solids has been observed previously $[10,14]$. However, these corrosion rates are unacceptably high $(>150$ mpy) and therefore the nitric acid reagent at the high temperature and high concentration condition should not be utilized for chemical cleaning.

Figure 4-7 shows the corrosion rates for the high temperature, low concentration nitric acid based reagent. The corrosion rates ranged between 85 and 724 mpy. The corrosion rates for the tests with solids were less than or equal to the corrosion rate with reagent alone, except 
SRNL-STI-2010-00555, REV. 0

Table 4-3. General Corrosion Rates for Sulfuric Acid/Oxalic Acid Reagent Tests

\begin{tabular}{|c|c|c|c|c|c||}
\hline Test ID & $\begin{array}{c}\text { Sulfuric } \\
\text { Acid (M) }\end{array}$ & $\begin{array}{c}\text { Oxalic } \\
\text { Acid } \\
\mathbf{( w t . ~} \%)\end{array}$ & $\begin{array}{c}\text { Temperature } \\
\mathbf{(} \mathbf{C}^{\circ}\end{array}$ & $\begin{array}{c}\text { Oxide or } \\
\text { Simulant }\end{array}$ & $\begin{array}{c}\text { General } \\
\text { corrosion rate } \\
\text { (mpy) }\end{array}$ \\
\hline \hline 1 & 0.05 & 1 & 45 & None & 138 \\
\hline 2 & 0.25 & 1 & 45 & None & 405 \\
\hline 3 & 0.05 & 1 & 75 & None & 226 \\
\hline 4 & 0.25 & 1 & 75 & None & 2031 \\
\hline 5 & 0.05 & 1 & 75 & Magnetite & 87 \\
\hline 6 & 0.05 & 1 & 75 & Hematite & 258 \\
\hline 7 & 0.05 & 1 & 75 & Boehmite & 192 \\
\hline 8 & 0.05 & 1 & 75 & Gibbsite & 215 \\
\hline 9 & 0.05 & 1 & 75 & HM & NA \\
\hline 10 & 0.05 & 1 & 75 & PUREX & 72 \\
\hline 11 & 0.25 & 1 & 45 & Magnetite & 726 \\
\hline 12 & 0.25 & 1 & 75 & Magnetite & 1335 \\
\hline 13 & 0.25 & 1 & 45 & Hematite & 428 \\
\hline 14 & 0.25 & 1 & 75 & Hematite & 1127 \\
\hline 15 & 0.25 & 1 & 45 & Boehmite & 425 \\
\hline 16 & 0.25 & 1 & 75 & Boehmite & 825 \\
\hline 17 & 0.25 & 1 & 45 & Gibbsite & 162 \\
\hline 18 & 0.25 & 1 & 75 & Gibbsite & 604 \\
\hline 19 & 0.05 & 1 & 45 & HM & 13 \\
\hline 20 & 0.25 & 1 & 75 & HM & 770 \\
\hline 21 & 0.05 & 1 & 45 & PUREX & 81 \\
\hline 22 & 0.25 & 1 & 75 & PUREX & 440 \\
\hline & & & & & \\
\hline \hline
\end{tabular}


Table 4-4. General Corrosion Rates for Nitric Acid/Oxalic Acid Reagent Tests

\begin{tabular}{|c|c|c||c|c||c||}
\hline Test ID & $\begin{array}{c}\text { Nitric } \\
\text { Acid (M) }\end{array}$ & $\begin{array}{c}\text { Oxalic } \\
\text { Acid } \\
\mathbf{( w t . ~} \mathbf{~})\end{array}$ & $\begin{array}{c}\text { Temperature } \\
\mathbf{(} \mathbf{C}^{\mathbf{C})}\end{array}$ & $\begin{array}{c}\text { Oxide or } \\
\text { Simulant }\end{array}$ & $\begin{array}{c}\text { General } \\
\text { corrosion rate } \\
\mathbf{( m p y )}\end{array}$ \\
\hline \hline 1 & 0.1 & 1 & 45 & None & 54 \\
\hline 2 & 0.5 & 1 & 45 & None & 405 \\
\hline 3 & 0.1 & 1 & 75 & None & 289 \\
\hline 4 & 0.5 & 1 & 75 & None & 1848 \\
\hline 5 & 0.1 & 1 & 75 & Magnetite & 298 \\
\hline 6 & 0.1 & 1 & 75 & Hematite & 163 \\
\hline 7 & 0.1 & 1 & 75 & Boehmite & 198 \\
\hline 8 & 0.1 & 1 & 75 & Gibbsite & 426 \\
\hline 9 & 0.1 & 1 & 75 & HM & 724 \\
\hline 10 & 0.1 & 1 & 75 & PUREX & 85 \\
\hline 11 & 0.5 & 1 & 45 & Magnetite & 706 \\
\hline 12 & 0.5 & 1 & 75 & Magnetite & 1938 \\
\hline 13 & 0.5 & 1 & 45 & Hematite & 605 \\
\hline 14 & 0.5 & 1 & 75 & Hematite & 999 \\
\hline 15 & 0.5 & 1 & 45 & Boehmite & 367 \\
\hline 16 & 0.5 & 1 & 75 & Boehmite & 1396 \\
\hline 17 & 0.5 & 1 & 45 & Gibbsite & 1274 \\
\hline 18 & 0.5 & 1 & 75 & Gibbsite & 1685 \\
\hline 19 & 0.1 & 1 & 45 & HM & 87 \\
\hline 20 & 0.5 & 1 & 75 & HM & 1724 \\
\hline 21 & 0.1 & 1 & 45 & PUREX & 54 \\
\hline 22 & 0.5 & 1 & 75 & PUREX & 4313 \\
\hline
\end{tabular}

for the HM simulant and the gibbsite pure phase oxide. However, most of these corrosion rates were unacceptably high (>150 mpy) and therefore, the nitric acid reagent at the high temperature and low concentration condition should not be utilized. The lone exception was the PUREX simulant, with a corrosion rate of 85 mpy.

Figure 4-8 shows the corrosion rates for the low temperature, high concentration nitric acid based reagent. The corrosion rates ranged between 367 and $1274 \mathrm{mpy}$. In this case the corrosion rates for the tests with solids were generally greater than or equal to the corrosion rate with reagent alone, with the gibbsite pure phase oxide exhibiting the greatest corrosion rate. It is interesting to note that the corrosion rate for the boehmite pure oxide phase was essentially the same as the corrosion rate for the nitric acid based reagent. This result suggests that boehmite had not dissolved in the solution. Indeed, other tests have shown that boehmite dissolution is ineffective at temperatures less than $70{ }^{\circ} \mathrm{C} \mathrm{[16].} \mathrm{All} \mathrm{corrosion} \mathrm{rates}$ were unacceptably high ( $>150 \mathrm{mpy})$ and therefore, the nitric acid reagent at the low temperature and high concentration condition should not be utilized for chemical cleaning. 
Figure 4-9 shows the corrosion rates for the low temperature, low concentration nitric acid based reagent. In this case, only the HM and PUREX sludge simulants were evaluated. The corrosion rates ranged between 54 and $87 \mathrm{mpy}$. In this case the corrosion rates for the tests with solids were slightly greater than or equal to the corrosion rate with reagent alone, with the HM sludge simulant exhibiting the greatest corrosion rate. These corrosion rates are manageable ( $<150 \mathrm{mpy})$ and therefore, the nitric acid reagent at the low temperature and low concentration condition may be considered for use in the chemical cleaning process.

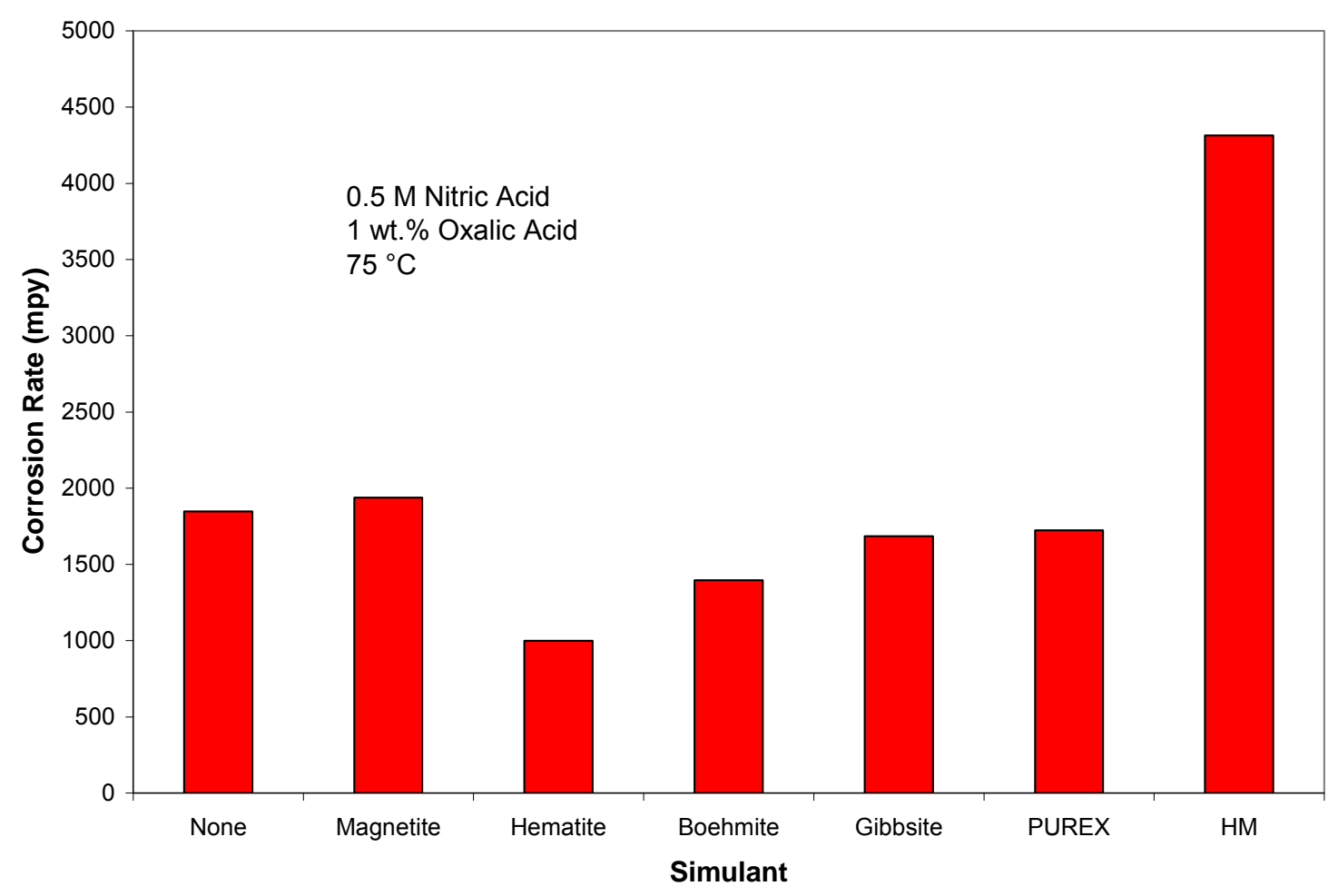

Figure 4-6. Corrosion rates for $0.5 \mathrm{M}$ nitric acid with various solid phases at $75^{\circ} \mathrm{C}$. 
SRNL-STI-2010-00555, REV. 0

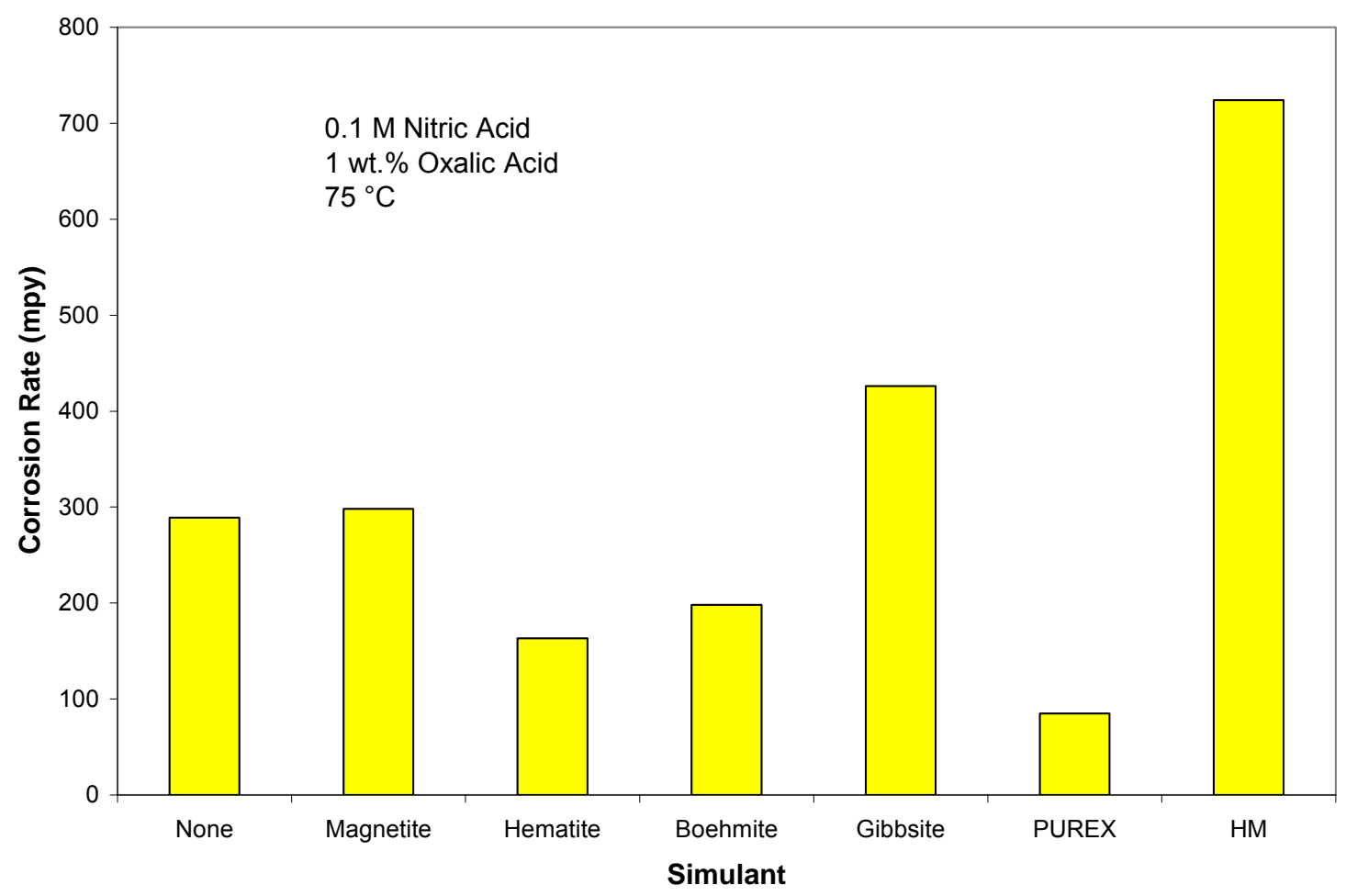

Figure 4-7. Corrosion rates for $0.1 \mathrm{M}$ nitric acid with various solid phases at $75^{\circ} \mathrm{C}$.

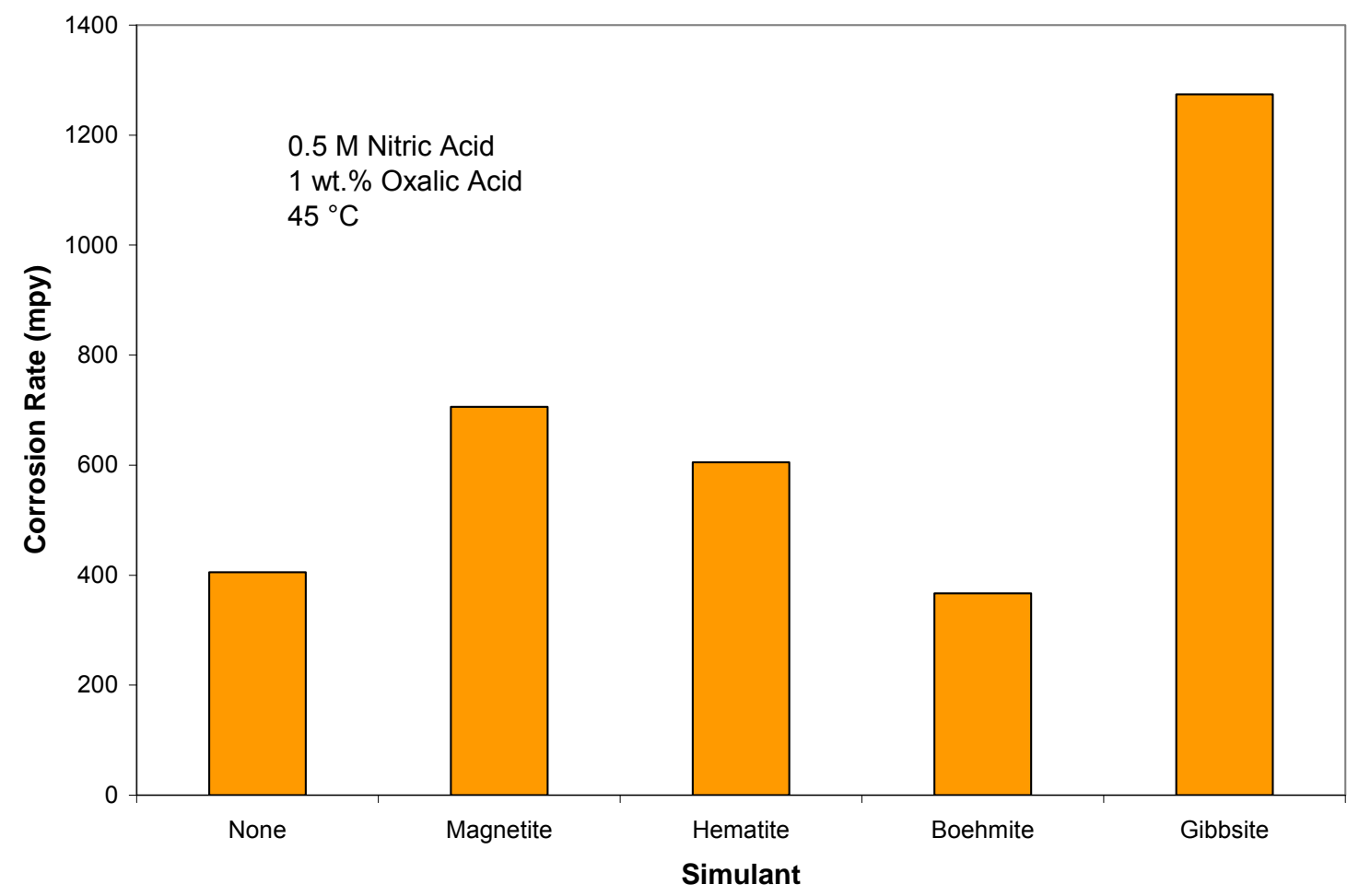

Figure 4-8. Corrosion rates for $0.5 \mathrm{M}$ nitric acid with various solid phases at $45^{\circ} \mathrm{C}$. 


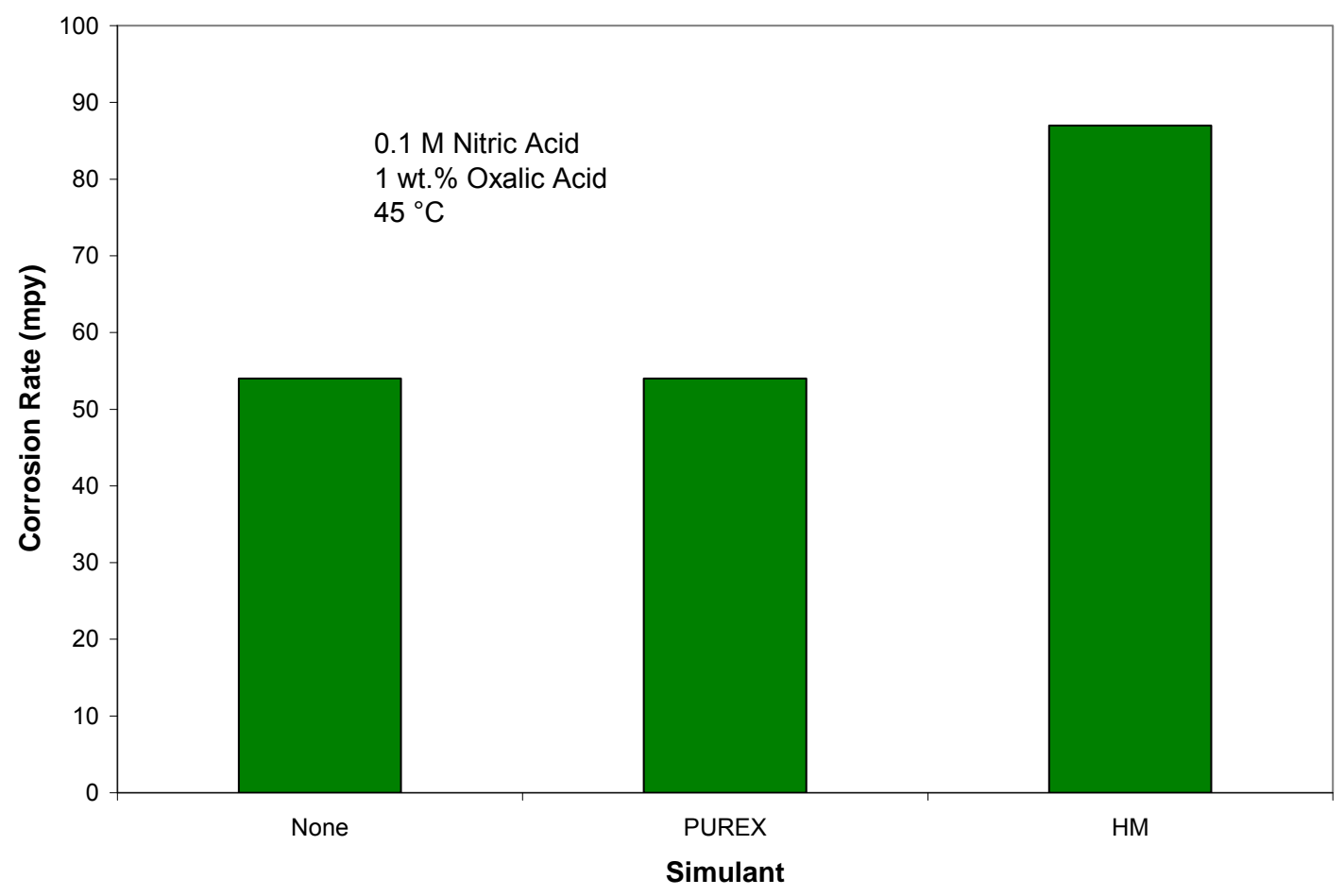

Figure 4-9. Corrosion rates for $0.1 \mathrm{M}$ nitric acid with sludge simulants at $45^{\circ} \mathrm{C}$.

Figure 4-10 shows the corrosion rates for the high temperature, high concentration sulfuric acid based reagent. The corrosion rates ranged between 440 and $2031 \mathrm{mpy}$. In all cases, the corrosion rates for the tests with solids were less than or equal to the corrosion rate with reagent alone. However, all of these corrosion rates were unacceptably high ( $>150 \mathrm{mpy})$ and therefore, the sulfuric acid reagent at the high temperature and high concentration condition should not be utilized for chemical cleaning.

Figure 4-11 shows the corrosion rates for the high temperature, low concentration sulfuric acid based reagent. The corrosion rates ranged between 72 and 258 mpy. The corrosion rates for the tests with solids are less than or equal to the corrosion rate with reagent alone, except for hematite pure oxide phase test. However, most of these corrosion rates are unacceptably high ( $>150 \mathrm{mpy})$ and therefore the sulfuric acid reagent at the high temperature and low concentration condition should not be utilized for chemical cleaning. The exceptions are the magnetite pure oxide and the PUREX simulant, with corrosion rates of 87 and 72 mpy, respectively.

Figure 4-12 shows the corrosion rates for the low temperature, high concentration sulfuric acid based reagent. The corrosion rates ranged between 162 and $726 \mathrm{mpy}$. In this case the corrosion rates for the tests with solids were generally greater than or equal to the corrosion rate with reagent alone, with the magnetite pure phase oxide exhibiting the greatest corrosion rate. The test with the gibbsite pure phase oxide had the lowest corrosion rate (i.e., 162 mpy). Again the corrosion rate for the boehmite pure oxide phase was essentially the same 
as the corrosion rate for the nitric acid based reagent, which suggests that boehmite had not dissolved in the solution. All of these corrosion rates were unacceptably high ( $>150 \mathrm{mpy})$ and therefore the sulfuric acid reagent at the low temperature and high concentration condition should not be utilized for chemical cleaning.

Figure 4-13 shows the corrosion rates for the low temperature, low concentration sulfuric acid based reagent. In this case, only the HM and PUREX sludge simulants were evaluated. The corrosion rates ranged between 13 and 138 mpy. The corrosion rates for the tests with solids were less than or equal to the corrosion rate with reagent alone, with the lowest corrosion rate observed for the HM waste. These corrosion rates are manageable $(<150 \mathrm{mpy})$ and therefore, the sulfuric acid reagent at the low temperature and low concentration condition may be considered for use in chemical cleaning.

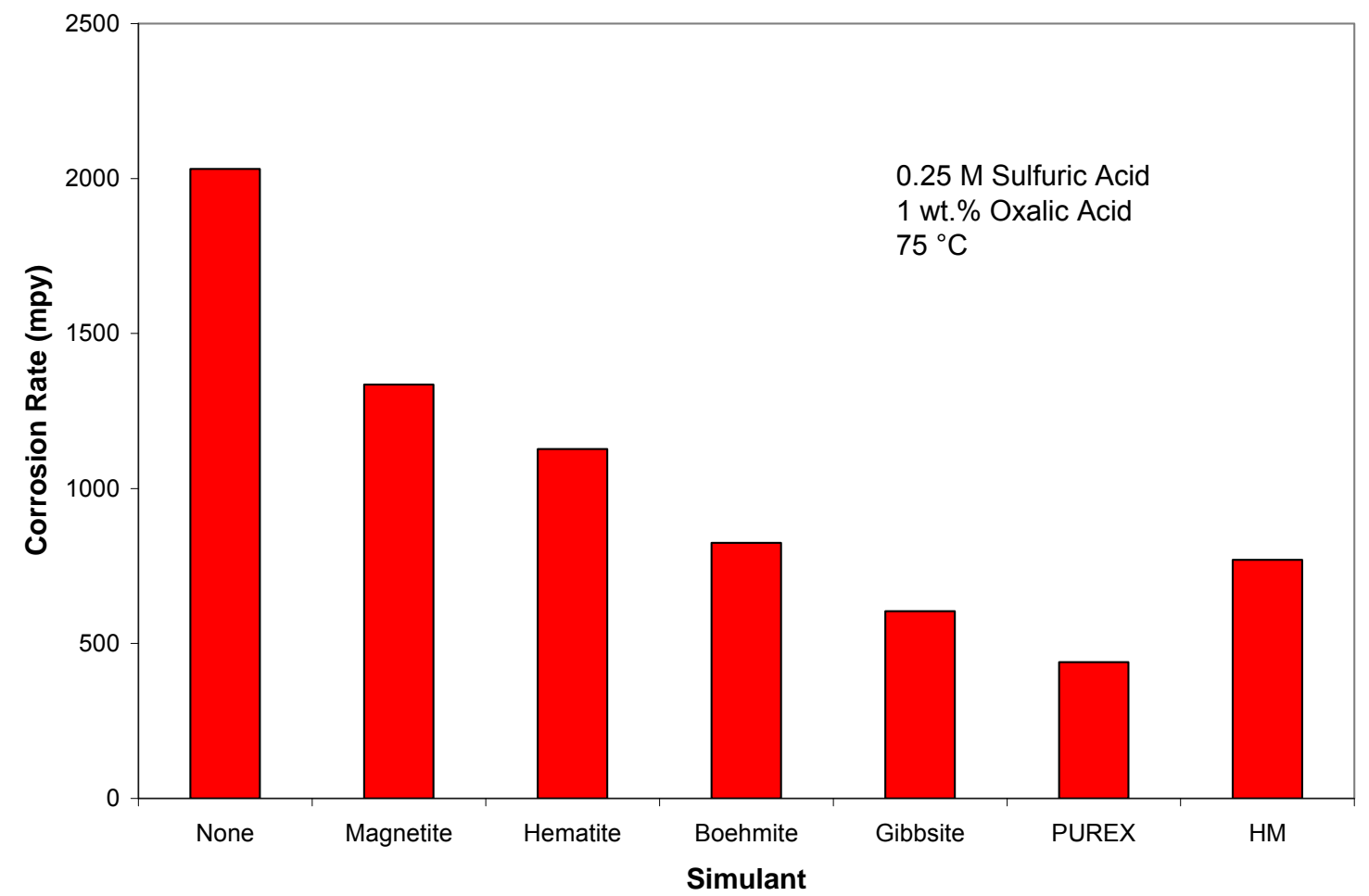

Figure 4-10. Corrosion rates for $0.25 \mathrm{M}$ sulfuric acid with various solid phases at $75^{\circ} \mathrm{C}$. 


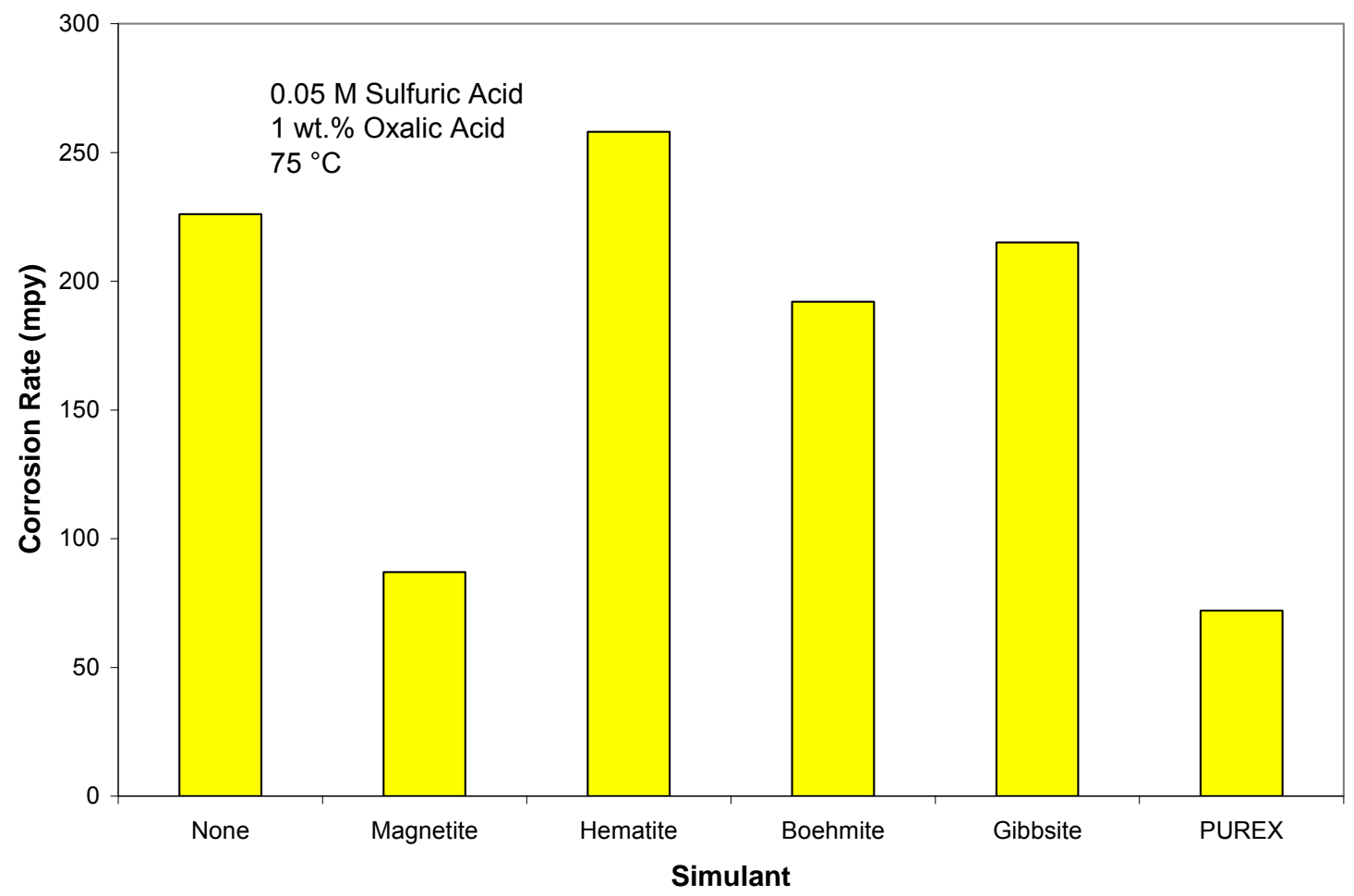

Figure 4-11. Corrosion rates for $0.05 \mathrm{M}$ sulfuric acid with various solid phases at $75^{\circ} \mathrm{C}$.

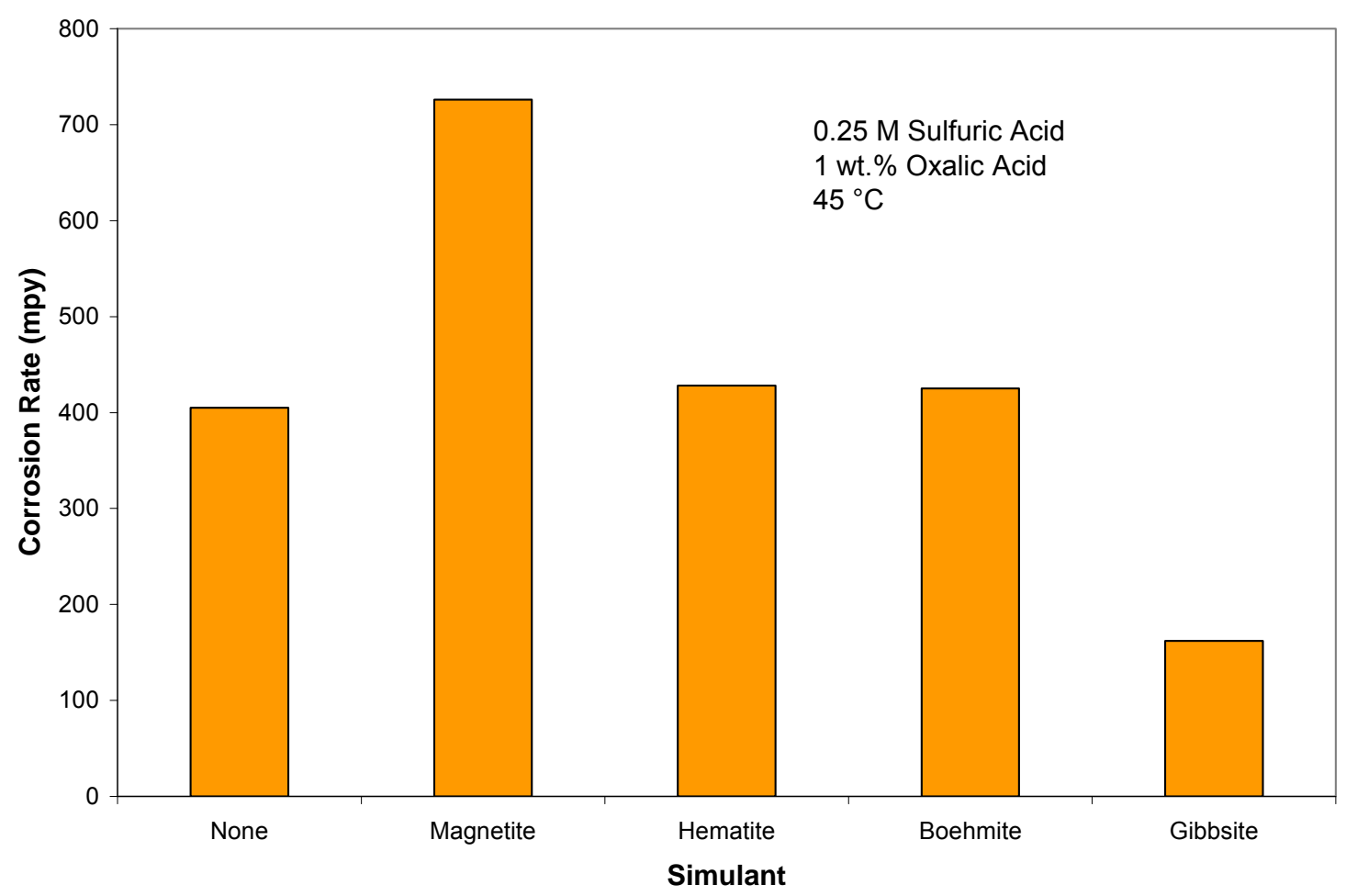

Figure 4-12. Corrosion rates for $0.25 \mathrm{M}$ sulfuric acid with various solid phases at $45^{\circ} \mathrm{C}$. 


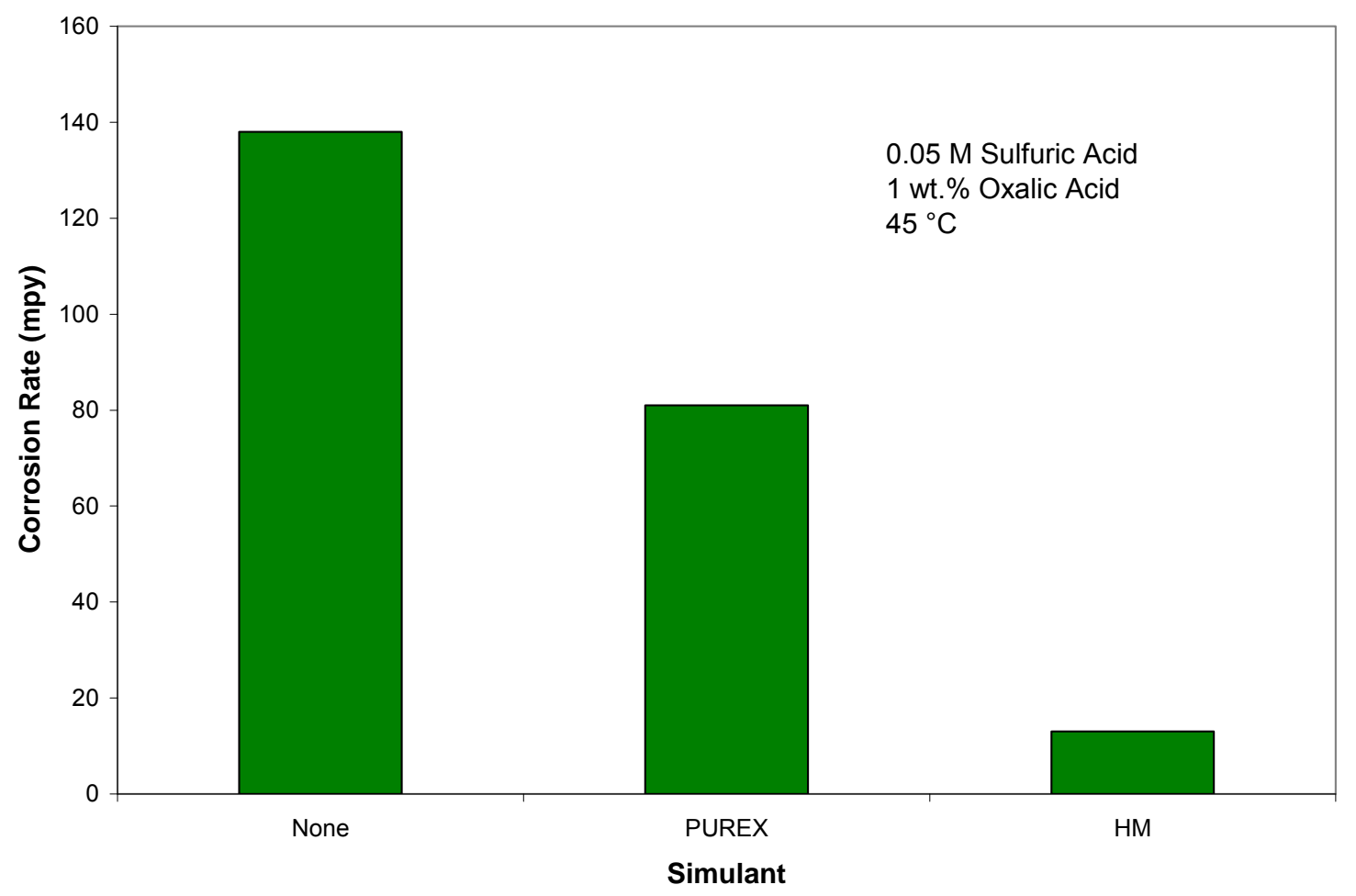

Figure 4-13. Corrosion rates for $0.05 \mathrm{M}$ sulfuric acid with sludge simulants at $45^{\circ} \mathrm{C}$.

\subsection{CATHODIC POLARIZATION TEST RESULTS}

As mentioned previously, the results of the Cathodic Polarization tests can provide information as to the kinetics of the cathodic reaction. This information, combined with the OCP data, can provide information on the propensity for hydrogen evolution. The important parameters collected from these curves are the cathodic Tafel slope $\left(\beta_{c}\right)$ and the exchange current density $\left(i_{0}\right)$. Figure $4-14$ shows the results of two cathodic polarization tests. Curve (a) is for the high concentration, low temperature nitric acid reagent, while curve (b) is for the high concentration, low temperature sulfuric acid reagent with the magnetite pure phase solids. These results show how the presence of solids in the solution changes the kinetics of the cathodic reaction. The large negative slope, observed for curve (b), is typical of a mass transport controlled reaction of the active species with the metal surface. The slope of curve (a), is typical of an activation controlled (i.e., kinetics of charge transfer) reaction. It is interesting to note that $i_{o}$ for each of the curves is approximately the same. These results suggest that the general corrosion rate should be approximately the same, as was the case (see Section 4.2). 
SRNL-STI-2010-00555, REV. 0

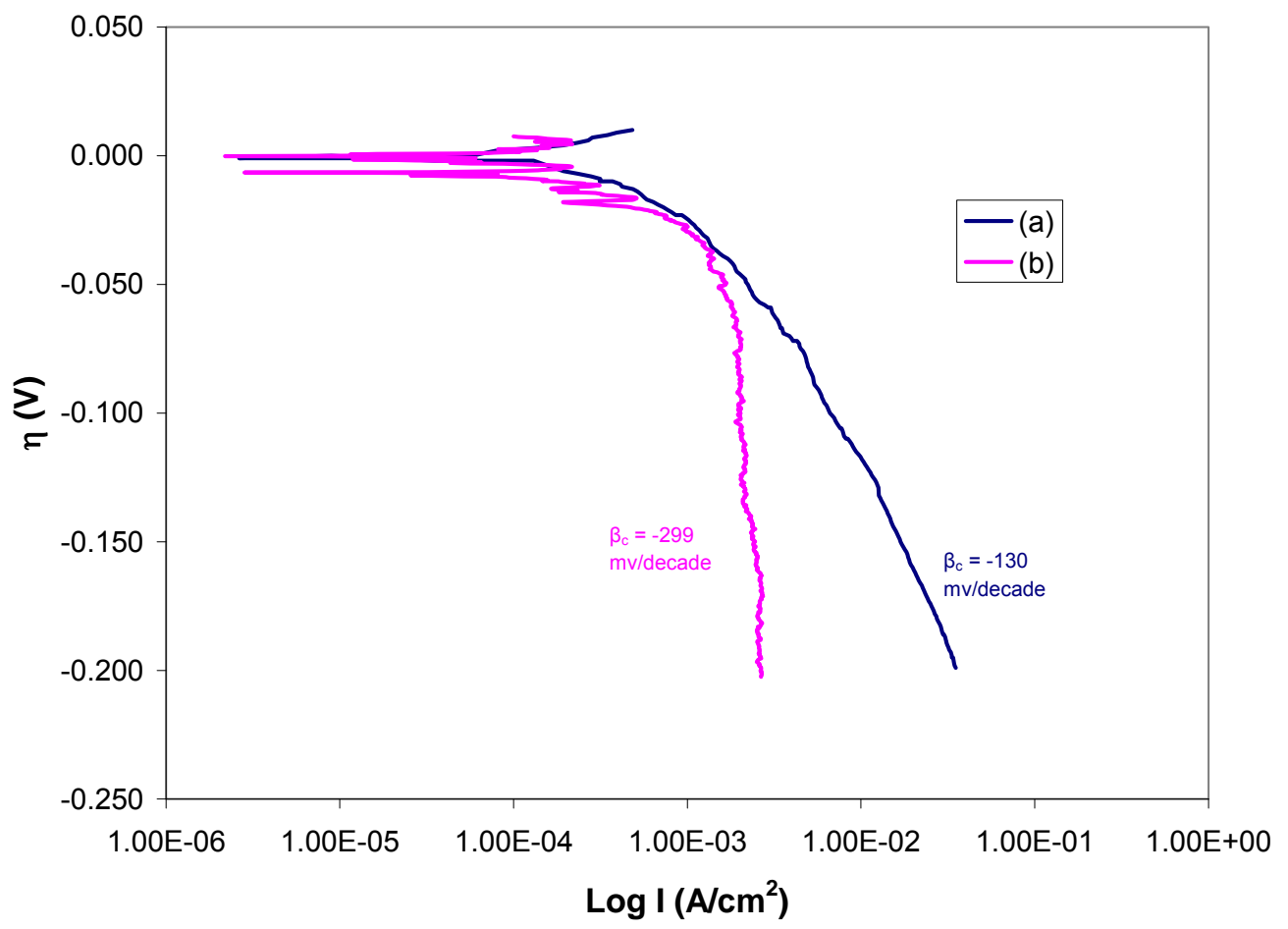

Figure 4-14. Cathodic polarization curves in: (a) $0.5 \mathrm{M}$ nitric and 1 wt. $\%$ oxalic acids at $45^{\circ} \mathrm{C}$, and (b) magnetite pure phase oxide, $0.25 \mathrm{M}$ sulfuric acid and $1 \mathrm{wt} \%$ oxalic acid at $45{ }^{\circ} \mathrm{C}$.

The results of all the Cathodic Polarization tests are shown in Tables 4-5 and 4-6. The propensity for hydrogen evolution was evaluated by considering the OCP and the calculated transfer coefficient, $\alpha$. If the OCP was more active than $-0.266 \mathrm{~V}$ vs. $\mathrm{Ag} / \mathrm{AgCl}$ and $\alpha$ was between 0.4 and 0.6 there is a propensity for hydrogen evolution. The results in the tables show that hydrogen evolution is likely for only 5 of the 44 tested conditions (see yellow highlighted results). Three of these five tested conditions were with the nitric acid based reagent only. This may imply that during the initial exposure of the nitric acid based reagent to a carbon steel tank, hydrogen may evolve due to corrosion. However, as the oxides are dissolved (particularly the iron oxides), the propensity for hydrogen evolution diminishes. The remaining two test conditions were with the boehmite pure phase oxide. In addition to aluminum oxides, the sludges in the waste tanks contained iron oxides as well. These phases were shown to reduce the likelihood of hydrogen evolution. The HM sludge simulant that contained both of these oxide phases, in fact, showed little propensity for hydrogen evolution (see tests 19 and $21 \mathrm{CP}$ results). 
Table 4-5. Cathodic Polarization Parameters for Sulfuric Acid

\begin{tabular}{|c|c|c|c|c|}
\hline Test ID & $\begin{array}{c}\text { OCP vs. } \\
\mathrm{Ag} / \mathrm{AgCl} \\
(\mathrm{V})\end{array}$ & $\mathrm{i}_{\mathrm{o}}\left(\mathrm{A} / \mathrm{cm}^{2}\right)$ & $\beta_{\mathrm{c}}(\mathrm{mV} /$ decade $)$ & $\alpha$ \\
\hline 1 & -0.47 & $6.75 \mathrm{E}-04$ & -252 & 0.25 \\
\hline 2 & -0.471 & $3.08 \mathrm{E}-03$ & -259 & 0.24 \\
\hline 3 & -0.458 & $2.00 \mathrm{E}-03$ & -281 & 0.25 \\
\hline 4 & -0.445 & NA & $\mathrm{NA}$ & NA \\
\hline 5 & -0.2 & $4.49 \mathrm{E}-05$ & -130 & 0.53 \\
\hline 6 & -0.205 & $2.72 \mathrm{E}-03$ & -215 & 0.32 \\
\hline 7 & -0.482 & $6.80 \mathrm{E}-04$ & -163 & 0.42 \\
\hline 8 & -0.595 & $1.17 \mathrm{E}-03$ & -391 & 0.18 \\
\hline 9 & -0.126 & NA & $\mathrm{NA}$ & NA \\
\hline 10 & -0.159 & $2.37 \mathrm{E}-05$ & -168 & 0.41 \\
\hline 11 & -0.119 & $4.54 \mathrm{E}-04$ & -299 & 0.21 \\
\hline 12 & -0.5 & $2.54 \mathrm{E}-03$ & -381 & 0.18 \\
\hline 13 & -0.291 & $1.33 \mathrm{E}-03$ & -400 & 0.16 \\
\hline 14 & -0.142 & $2.67 \mathrm{E}-03$ & -380 & 0.18 \\
\hline 15 & -0.455 & $2.16 \mathrm{E}-03$ & -305 & 0.21 \\
\hline 16 & -0.509 & $3.64 \mathrm{E}-03$ & -318 & 0.22 \\
\hline 17 & -0.496 & NA & $\mathrm{NA}$ & NA \\
\hline 18 & -0.549 & $2.84 \mathrm{E}-03$ & -353 & 0.20 \\
\hline 19 & -0.459 & $1.10 \mathrm{E}-04$ & -240 & 0.26 \\
\hline 20 & -0.422 & $2.09 \mathrm{E}-03$ & -223 & 0.31 \\
\hline 21 & -0.193 & NA & NA & NA \\
\hline 22 & -0.109 & $1.53 \mathrm{E}-03$ & -542 & 0.13 \\
\hline
\end{tabular}


Table 4-6. Cathodic Polarization Parameters for Nitric Acid

\begin{tabular}{|c|c|c|c|c|}
\hline Test ID & $\begin{array}{c}\text { OCP vs. } \\
\text { Ag/AgCl } \\
(\mathrm{V})\end{array}$ & $\mathrm{i}_{\mathrm{o}}\left(\mathrm{A} / \mathrm{cm}^{2}\right)$ & $\beta_{\mathrm{c}}(\mathrm{mV} /$ decade $)$ & $\alpha$ \\
\hline 1 & -0.358 & $2.80 \mathrm{E}-04$ & -171 & 0.37 \\
\hline 2 & -0.407 & $6.60 \mathrm{E}-04$ & -130 & 0.49 \\
\hline 3 & -0.357 & $1.01 \mathrm{E}-03$ & -179 & 0.39 \\
\hline 4 & -0.375 & NA & NA & NA \\
\hline 5 & -0.265 & $2.21 \mathrm{E}-03$ & -344 & 0.20 \\
\hline 6 & -0.28 & $1.49 \mathrm{E}-03$ & -566 & 0.12 \\
\hline 7 & -0.373 & $1.01 \mathrm{E}-03$ & -259 & 0.27 \\
\hline 8 & -0.375 & $2.88 \mathrm{E}-03$ & -1058 & 0.07 \\
\hline 9 & -0.478 & $3.12 \mathrm{E}-03$ & -366 & 0.19 \\
\hline 10 & -0.324 & $3.09 \mathrm{E}-04$ & -325 & 0.21 \\
\hline 11 & -0.202 & $4.23 \mathrm{E}-03$ & -966 & 0.07 \\
\hline 12 & -0.336 & NA & NA & NA \\
\hline 13 & -0.297 & $2.29 \mathrm{E}-03$ & -423 & 0.15 \\
\hline 14 & -0.198 & $5.78 \mathrm{E}-03$ & -270 & 0.26 \\
\hline 15 & -0.402 & $1.04 \mathrm{E}-03$ & -153 & 0.41 \\
\hline 16 & -0.37 & $5.59 \mathrm{E}-03$ & -213 & 0.32 \\
\hline 17 & -0.415 & NA & NA & NA \\
\hline 18 & -0.439 & $7.81 \mathrm{E}-03$ & -382 & 0.18 \\
\hline 19 & -0.166 & $6.59 \mathrm{E}-04$ & -420 & 0.15 \\
\hline 20 & -0.408 & $1.87 \mathrm{E}-02$ & -325 & 0.21 \\
\hline 21 & -0.292 & $4.20 \mathrm{E}-04$ & -360 & 0.18 \\
\hline 22 & -0.394 & $5.14 \mathrm{E}-03$ & -220 & 0.31 \\
\hline & & & &
\end{tabular}




\subsection{CYCLIC POTENTIODYNAMIC POLARIZATION RESULTS}

The CPP tests were performed to determine the susceptibility of carbon steel to localized corrosion, such as pitting in these chemical cleaning environments. Of the 43 cyclic polarization tests that were performed, nine showed indications of susceptibility to localized attack. Figure 4-15 shows a CPP plot, which exhibited positive hysterisis (i.e., no susceptibility to localized attack). Additionally, the resulting curve exhibited no clear passive region (i.e., the current continues to increase as the potential is scanned toward more positive potentials) or breakdown potentials, which usually characterize localized corrosion behavior in CPP tests. Figure 4-16 is post-test photograph of the carbon steel working electrode. As expected, this sample exhibited severe general corrosion.

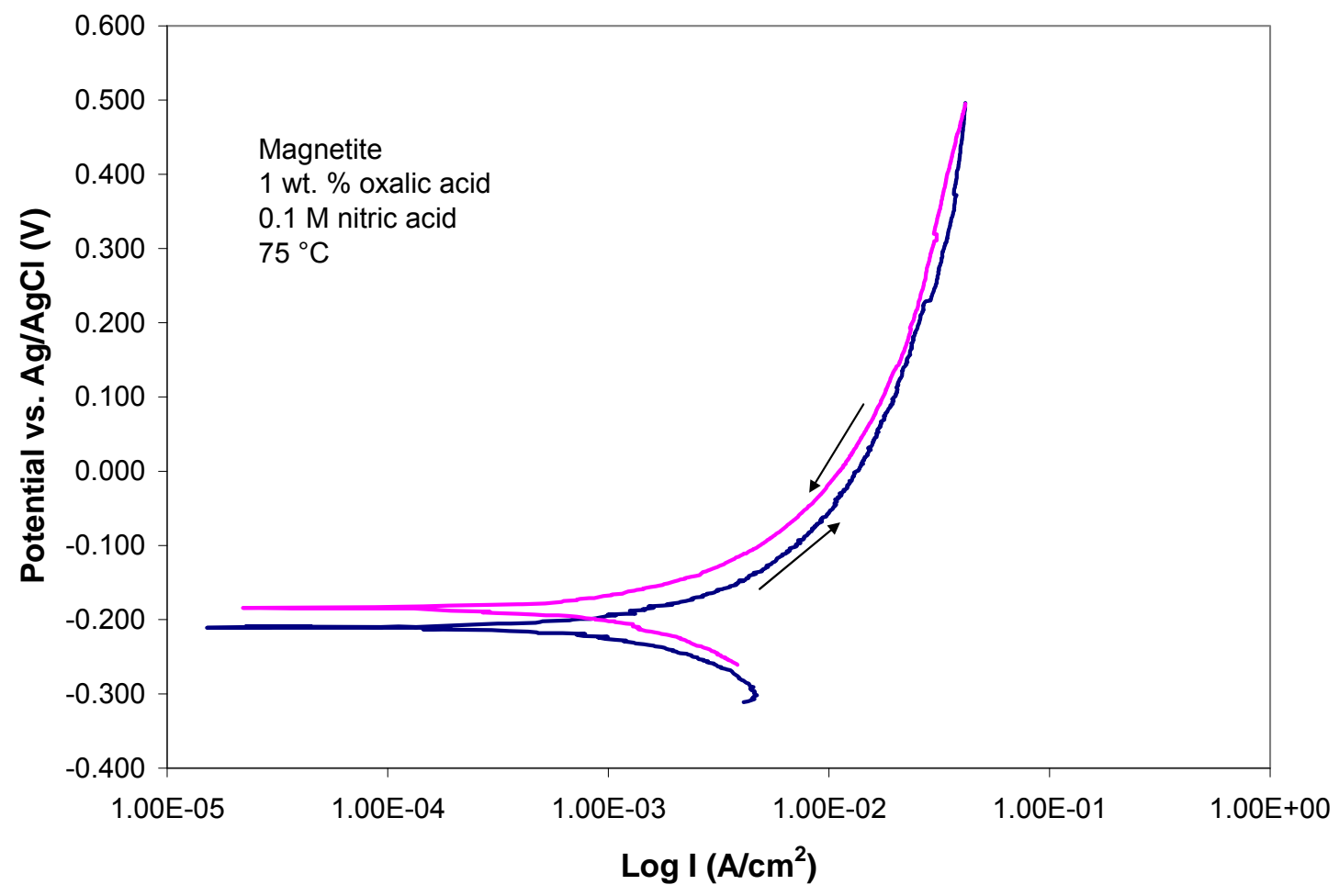

Figure 4-15. CPP diagram for carbon steel with magnetite in $0.1 \mathrm{M}$ nitric and 1 wt. \% oxalic acids at $75^{\circ} \mathrm{C}$. 


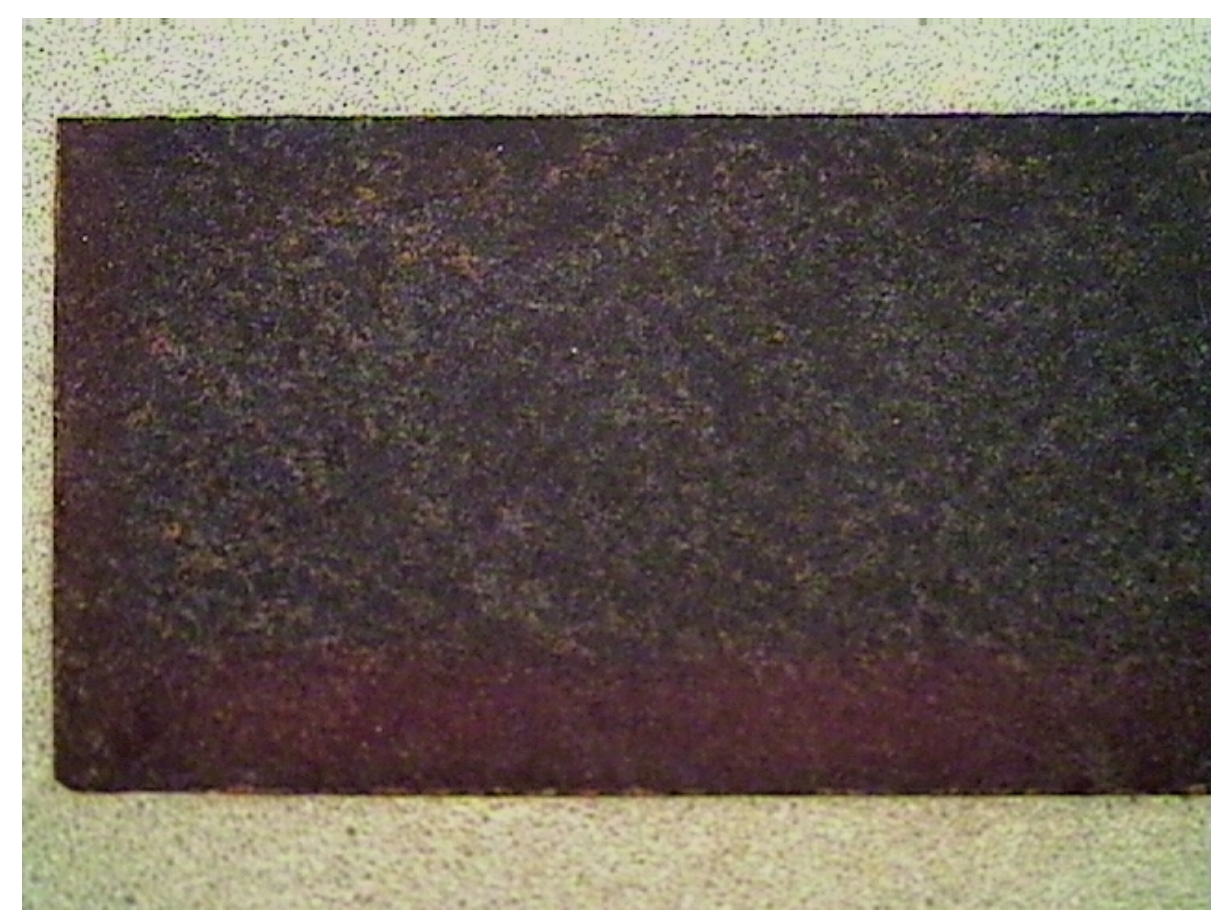

Figure 4-16. Electrode micrograph after exposure to magnetite in $0.1 \mathrm{M}$ nitric and 1 wt. $\%$ oxalic acids at $75^{\circ} \mathrm{C}$ (magnification 1x).

The environmental conditions for the nine tests that exhibited evidence of localized corrosion are summarized in Table 4-7. The table also shows that there were two categories of hysterisis observed: Positive and Cross-over, positive. A CPP curve that illustrates positive hysterisis is shown in Figure 4-17. A high current density and a reverse scan current density that was always greater than the forward scan current density were observed. Post-test visual observations of the sample revealed severe pitting on the surface in the midst of a passive ferrous oxalate/metal oxide surface film (See Figure 4-18). CPP curves that illustrate the cross-over, positive hysterisis are shown in Figures 4-19 and 4-21. In these cases, the reverse scan current density was initially less than the forward scan current density, but as the scan continued, positive hysterisis was observed. This type of result is observed in tests where the pit initiation has been delayed. Thus, if pits are observed they tend to be small. A long delay in the cross-over (i.e., the cross-over occurs at a more negative potential), low current densities, and the appearance of a clear passive region are indicators of reduced pitting corrosion. Figures 4-20 and 4-22 show the post-test samples from these two tests. A majority of the surface was covered with the passive ferrous oxalate/metal oxide film and only small indications of pitting were observed. 
Table 4-7. Summary of CPP Results for Tests Exhibiting Pitting

\begin{tabular}{||c|c|c||c|c|c||}
\hline Mineral Acid & Oxide & Acid (M) & Temp. $\left({ }^{\circ} \mathrm{C}\right)$ & Hysterisis & $\begin{array}{c}\text { Visual } \\
\text { Observations }\end{array}$ \\
\hline \hline Sulfuric & Magnetite & 0.05 & 75 & Positive & Severe pitting \\
\hline Sulfuric & Hematite & 0.05 & 75 & Positive & NA \\
\hline Sulfuric & PUREX & 0.05 & 75 & $\begin{array}{c}\text { Cross-over, } \\
\text { positive }\end{array}$ & Pitting \\
\hline Sulfuric & Magnetite & 0.25 & 45 & Positive & NA \\
\hline Sulfuric & PUREX & 0.05 & 45 & $\begin{array}{c}\text { Cross-over, } \\
\text { positive }\end{array}$ & Minor pitting \\
\hline Sulfuric & HM & 0.05 & 45 & $\begin{array}{c}\text { Cross-over, } \\
\text { positive }\end{array}$ & NA \\
\hline Sulfuric & PUREX & 0.25 & 75 & $\begin{array}{c}\text { Cross-over, } \\
\text { pitting }\end{array}$ & Pitting \\
\hline Nitric & PUREX & 0.1 & 45 & $\begin{array}{c}\text { Cross-over, } \\
\text { positive }\end{array}$ & Pitting \\
\hline Nitric & HM & 0.1 & 45 & Positive & NA \\
\hline \hline
\end{tabular}

Figure 4-23 shows a CPP curve for a nitric acid test. The cross-over, positive hysterisis was observed for this test as well as minor pitting. Visual observations and micrographs of the specimen surface after acid contact confirmed that a majority of the surface was covered with the passive ferrous oxalate/metal oxide film with only a few small pits.. 


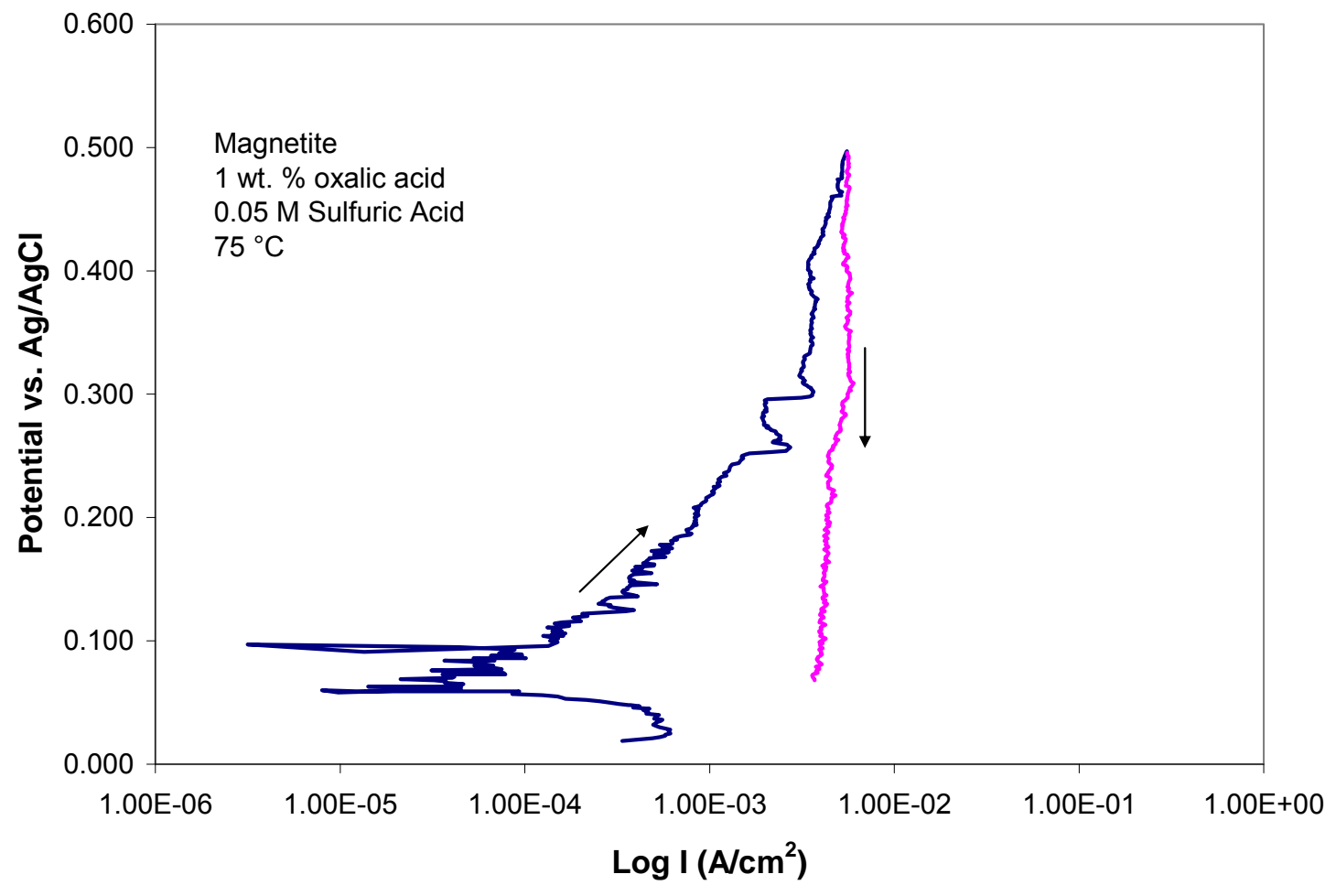

Figure 4-17. CPP diagram in 0.05 M sulfuric with magnetite at $75 \mathrm{C}$.

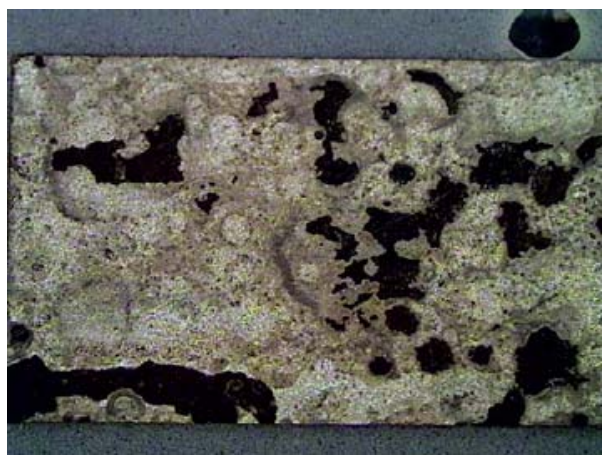

(a)

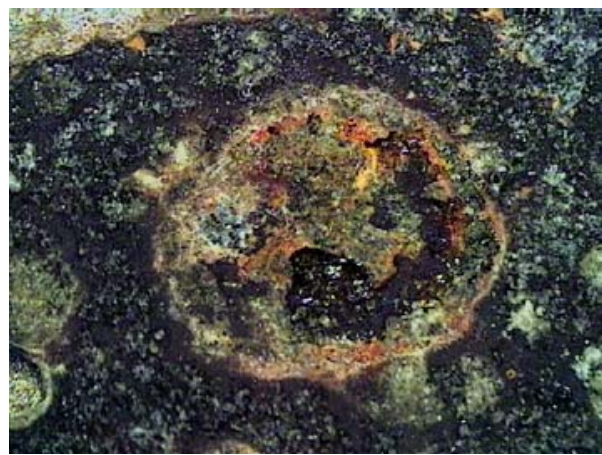

(b)

Figure 4-18. Electrode micrograph showing pitting after exposure to $0.05 \mathrm{M}$ sulfuric with magnetite at $75^{\circ} \mathrm{C}$ (magnification: $1 x$ for (a), $50 x$ for (b)). 


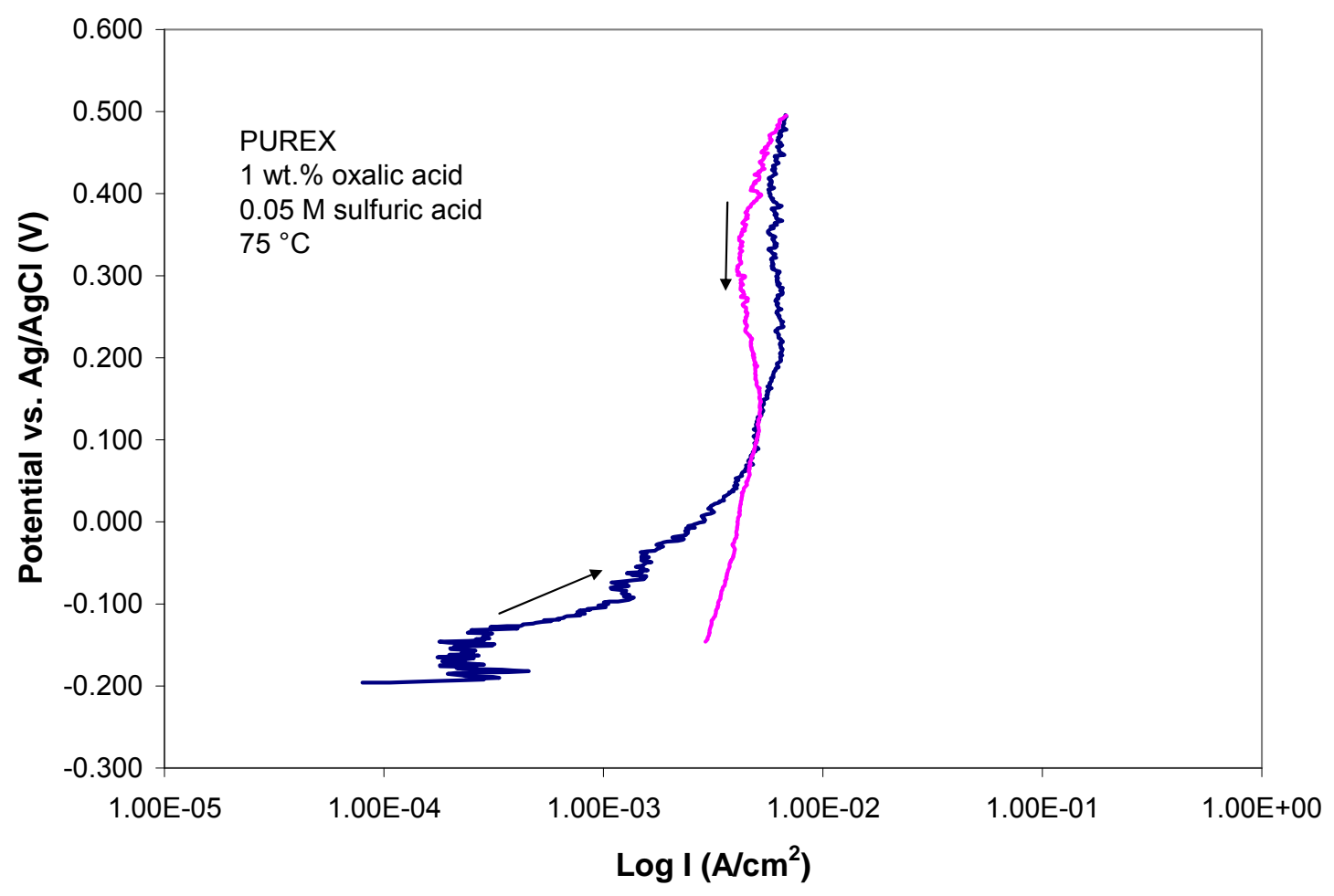

Figure 4-19. CPP diagram in $0.05 \mathrm{M}$ sulfuric with PUREX simulant at $75^{\circ} \mathrm{C}$.

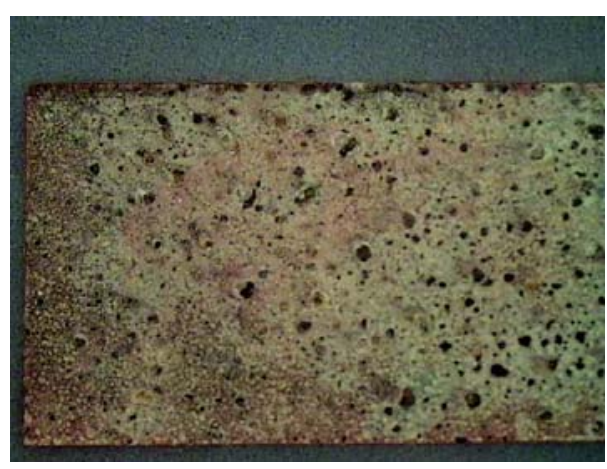

(a)

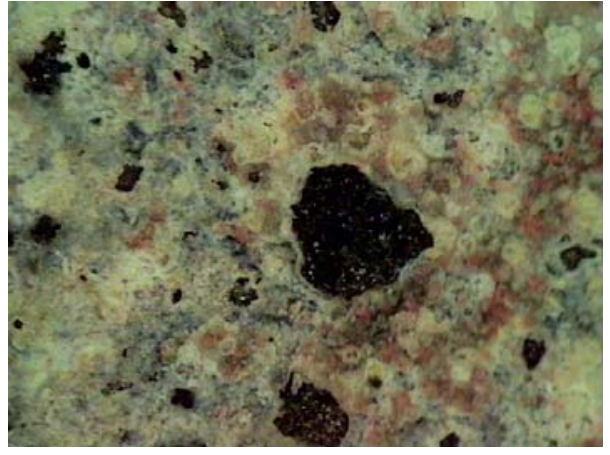

(b)

Figure 4-20. Electrode micrograph showing pitting after exposure to $0.05 \mathrm{M}$ sulfuric acid with PUREX at $75^{\circ} \mathrm{C}$ (magnification: $1 \mathrm{x}$ for (a), 90x for (b)). 


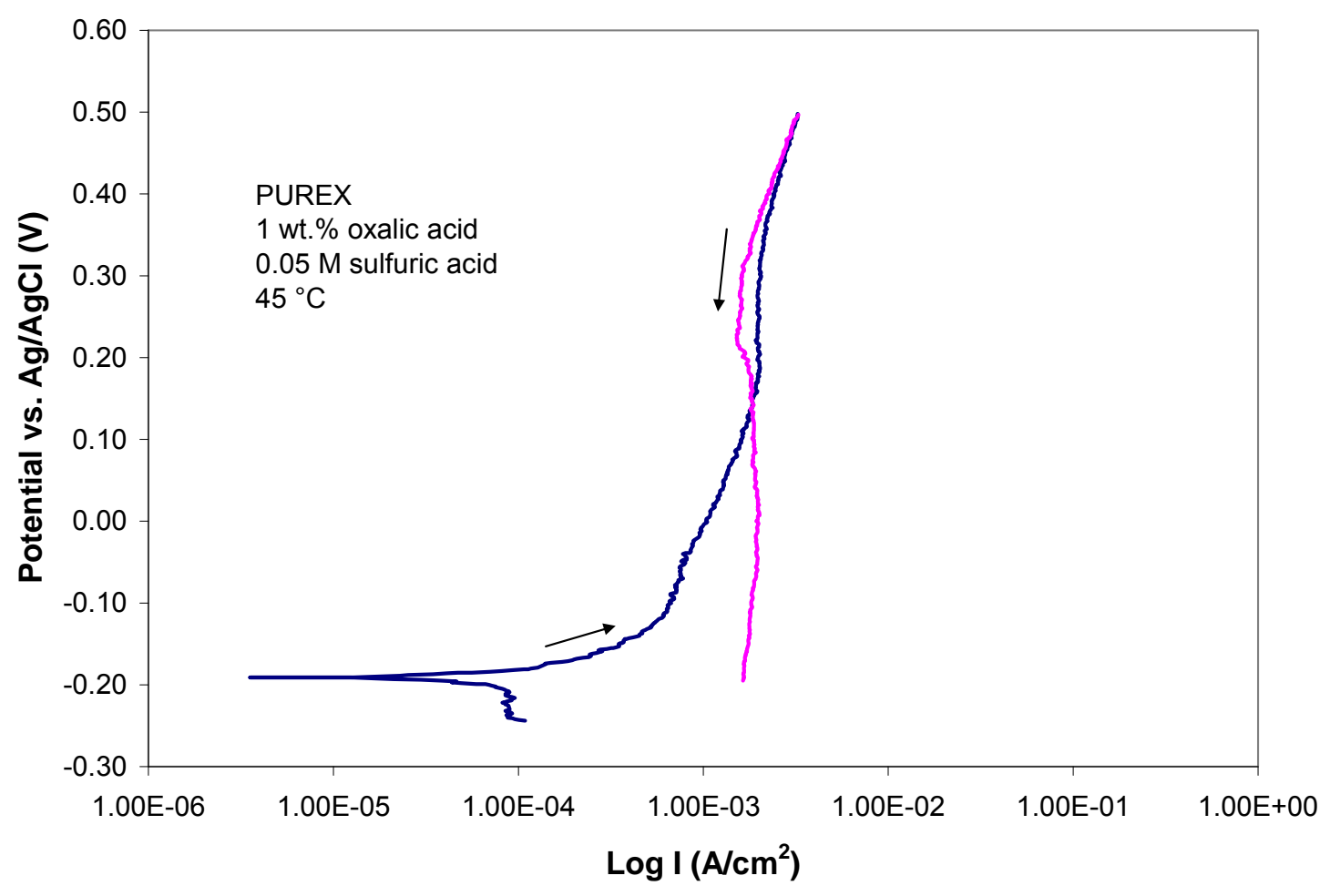

Figure 4-21. CPP diagram in $0.05 \mathrm{M}$ sulfuric acid with PUREX simulant at $45{ }^{\circ} \mathrm{C}$.

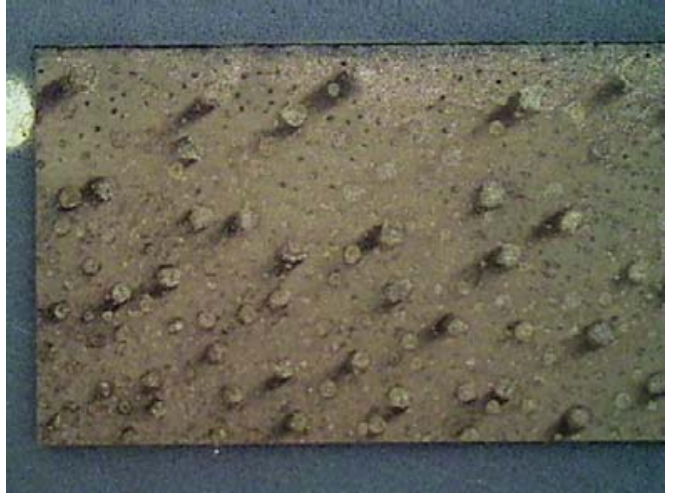

(a)

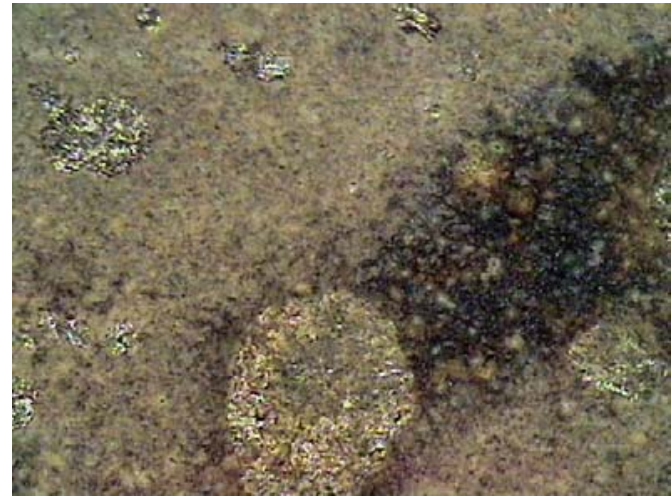

(b)

Figure 4-22. Electrode micrograph showing minor pitting after exposure to $0.05 \mathrm{M}$ sulfuric acid with PUREX simulant at $45^{\circ} \mathrm{C}$ (magnification: 1x for (a), 90x for (b)). 


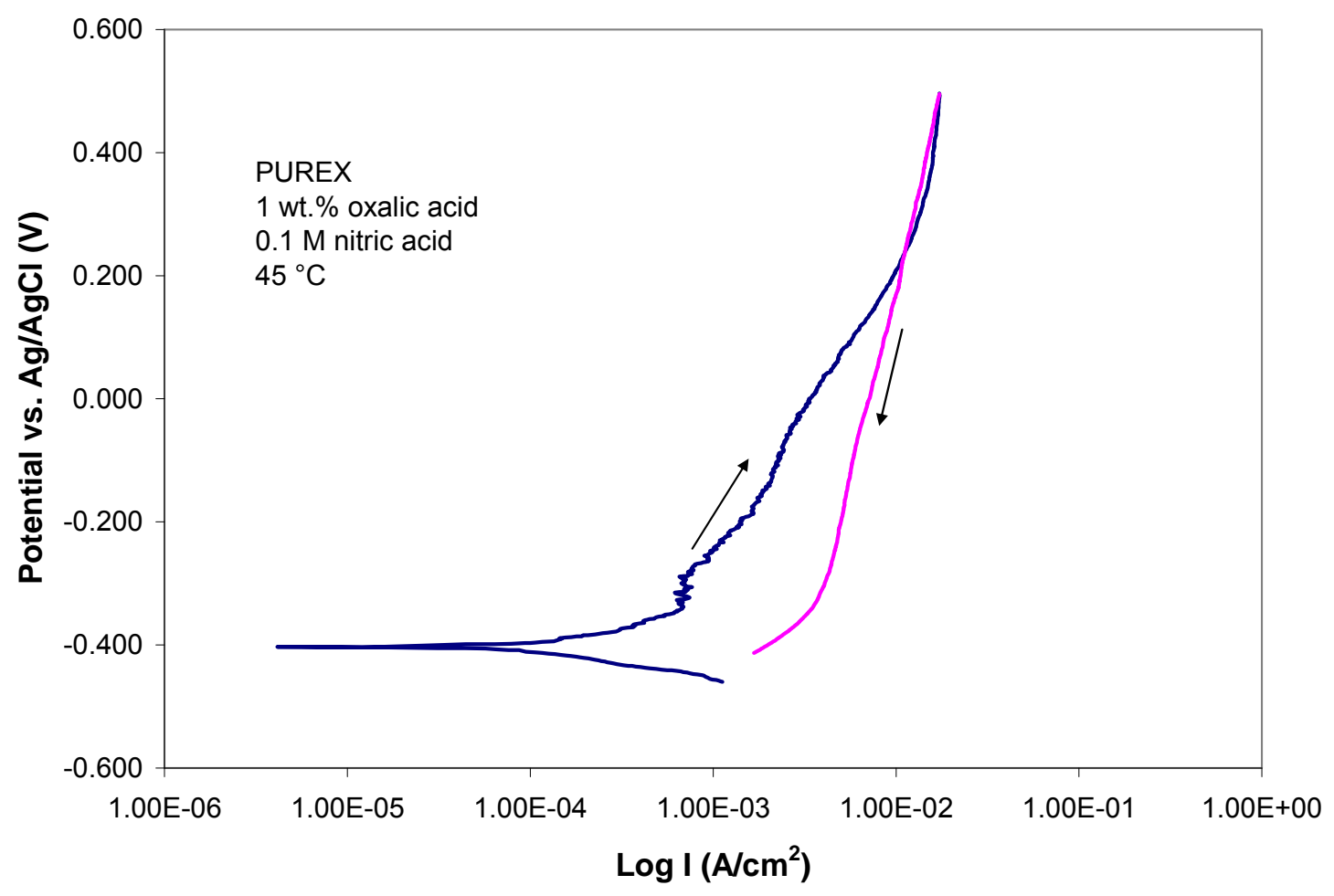

Figure 4-23. CPP diagram in 0.1M nitric acid with PUREX simulant at $45^{\circ} \mathrm{C}$.

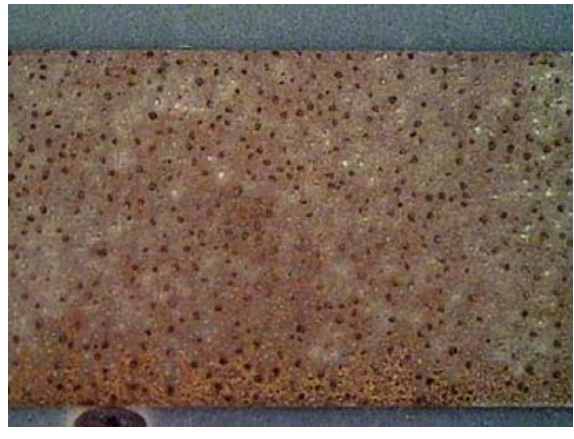

(a)

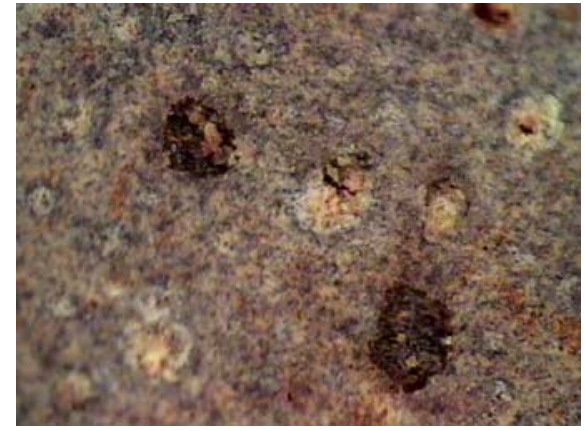

(b)

Figure 4-24. Electrode micrographs showing minor pitting after exposure to $0.1 \mathrm{M}$ nitric acid with PUREX simulant at $45^{\circ} \mathrm{C}$ (magnification: 1x for (a), 90x for (b)). 


\subsection{DISCUSSION}

Electrochemical tests were performed on carbon steel in various AECC environments, to evaluate the general corrosion rate, the susceptibility to localized corrosion (i.e., pitting) and to determine the propensity for hydrogen evolution. Based on the results of these tests, the following observations and conclusions were made.

- In both nitric and sulfuric acid based reagents, the low temperature and dilute concentration environment resulted in carbon steel corrosion rates that were less than 150 mpy. These rates are manageable in that chemical cleaning processes could proceed for limited time without significant wall thickness loss. Further optimization of the AECC process should focus on testing carbon steel in dilute concentration and low temperature regime.

- In general, for the nitric acid based reagent, the aluminum oxide phase environments resulted in higher corrosion rates than the iron oxide phase environments.

- In general, for the sulfuric acid based reagent, the iron oxide phase environments resulted in higher corrosion rates than the aluminum oxide phase environments.

- In general, for the nitric acid based reagent, the HM sludge simulant environments resulted in higher corrosion rates than the PUREX sludge simulant environments. This result agrees with the previous observation that the aluminum oxide phases are more aggressive than the iron oxide phase environments in the nitric acid reagent.

- Pitting was more likely to occur in the sulfuric acid based reagents than in the nitric acid based reagents.

- $\quad$ Pitting occurred only in the iron based pure oxide phases and the sludge simulants. No pitting was observed in the aluminum based pure oxide phases.

- Pitting tended to occur more frequently in the dilute mineral acid reagent tests.

- Pitting was more severe at the higher temperature for a given mineral acid concentration.

- Pitting was more severe at a higher mineral acid concentration for a given temperature.

- Based on the combined results of the OCP and cathodic polarization testing, there was a low propensity for hydrogen evolution in solutions in which sludge has been dissolved.

\subsection{CONCLUSIONS}

Electrochemical corrosion tests were conducted in 1 wt. \% oxalic acid at mineral acid concentrations above and below the optimal conditions for this oxalic acid concentration. Testing included pure reagents, pure iron and aluminum phases, and sludge simulants. Mineral acid concentrations greater than $0.2 \mathrm{M}$ and temperatures greater than $50{ }^{\circ} \mathrm{C}$ result in unacceptably high corrosion rates. Results showed that manageable corrosion rates of carbon steel can be achieved at dilute mineral acid concentrations (i.e. less than $0.2 \mathrm{M}$ ) and low temperatures based on the contact times involved. Therefore, it is recommended that future dissolution and corrosion testing be performed with a dilute mineral acid and a less concentrated oxalic acid (e.g., 0.5 wt.\%) that still promotes optimal dissolution. This 
recommendation requires the processing of greater water volumes than those for the baseline process during heel dissolution, but allows for minimization of oxalic acid additions. This recommendation requires the processing of greater water volumes than the baseline process during heel dissolution, but allows for minimization of oxalic acid additions.

\subsection{REFERENCES}

1. K. Adu-Wusu, M. J. Barnes, N. E. Bibler, J. R. Cantrell, F. F. Fondeur, B. A. Hamm, C. C. Herman, D. T. Hobbs, E. T. Ketusky, M. Singleton, M. E. Stallings, W. E. Stevens, and B. J. Wiersma. "Waste Tank Heel Chemical Cleaning Summary", WSRC-TR-2003-00401, September, 2003.

2. E. T. Ketusky, "Determination of An Alternative Technology for HLW Tank Chemical Cleaning”, WSRC-STI-2002007-00587, October, 2007.

3. M. S. Hay and D. C. Koopman. "Review of Alternative Enhanced Chemical Cleaning Options for SRS Waste Tanks", SRNL-STI-2009-00500, August, 2009.

4. C. J. Martino, "Evaluation of Alternative Chemical Cleaning and Enhanced Chemical Cleaning Methods", SRNL-L3100-2009-00118, June, 2009.

5. H. O. Bertholdt and D. Bege, "Method for Disposing of a Solution Containing an Organic Acid”, US Patent 5,958,247, Sept. 28, 1999.

6. M. R. Poirier and S. D. Fink, "Analysis of Solids Remaining Following Chemical Cleaning of Tank 5F”, SRNL-STI-2009-00492, December, 2009.

7. M. R. Poirier and S. D. Fink, "Analysis of Samples from Tank 6F Chemical Cleaning” SRNL-STI-2009-00493, February, 2010.

8. H. H. Uhlig, Corrosion Handbook, The Electrochemical Society, New York, NY, pp. 133-134, 1948.

9. B. D. Craig, Handbook of Corrosion Data, ASM International, Metals Park, OH, p.592, 1989.

10. D. T. Herman, et. al., "Investigating Hydrogen Generation and Corrosion in the Treatment Tank and the Potential Formation of a Floating Layer in the Neutralization Tank During Waste Tank Heel Chemical Cleaning”, WSRC-STI-2007-00209, April 30, 2007.

11. C. A. McKeel, “Type I Tank Liner Integrity Under Oxalic Acid Induced Corrosion”, T-CLC-F-00383, January 2008.

12. B. L. Garcia-Diaz, "Life Estimation of High Level Waste Tank Steel for H-Tank Farm Closure Performance Assessment”, SRN1-STI-2010-00047, March 2010.

13. B. J. Wiersma and K. H. Subramanian, "Corrosion Testing of Carbon Steel in Acid Cleaning Solutions”, WSRC-TR-2002-00427, September 2002.

14. B. J. Wiersma, "Treatment Tank Corrosion Studies for the Enhanced Chemical Cleaning Process", SRNL-STI-2010-00535, September, 2010.

15. R. E. Eibling, "Development of Hazardous Sludge Simulants for Enhanced Chemical Cleaning Tests", SRNL-STI-2010-00170 April, 2010.

16. W. D. King and M.S. Hay, "Alternative and Enhanced Chemical Cleaning: Basic Studies Results FY2010", to be issued.

17. R. L. Sindelar and B. J. Wiersma, "SRS High Level Waste Tank and Piping Systems - Structural Integrity Program and Topical Report”, WSRC-TR-95-0076, June 1995. 
18. Atlas of Electrochemical Equilibria in Aqueous Solutions, Ed. by M. Pourbaix, NACE International, Houston TX, p. 317, 1974.

19. "Standard Test Method for Conducting Potentiodynamic Polarization Resistance Measurements," ASTM G59-97, Reapproved in 2003.

20. M. Stern and A. L. Geary, J. Electrochemical Society,Vol. 104, No. 1, pp. 56-63, 1957.

21. J. R. Scully, "Polarization Resistance Method for Determination of Instantaneous Corrosion Rates", Corrosion, Vol. 56, No. 2, pp. 199-217, February 2000.

22. G. Kear and F. C. Walsh, "The Characteristics of a True Tafel Slope", Corrosion and Materials, Vol. 30, No. 6, December, 2005.

23. H. H. Uhlig, Corrosion and Corrosion Control, $2^{\text {nd }}$ Edition, John Wiley and Sons, NY, NY, 1971.

24. B. J. Wiersma, J. I. Mickalonis, "Determination of Corrosion Inhibitor Criteria for Type III/IIIA Tanks During Salt Dissolution Operations (U)", WSRC-STI-200600029, September, 2007.

25. J. B. Elder, "Tank Inspection NDE Results Tank 6, Including Summary of Waste Removal Support Activities in Tanks 5 and 6", SRNL-STI-2009-00560, February, 2010.

\subsection{ACKNOWLEDGEMENTS}

The author gratefully acknowledges K. J. Kalbaugh and M. A. Pettis for their assistance in executing the corrosion tests in the laboratory. Technical conversations with W. D. King, M. S. Hay, J. I. Mickalonis, and A. K. Roy were also valuable for interpreting and applying the corrosion data. 